\title{
A Noncanonical Postsynaptic Transport Route for a GPCR Belonging to the Serotonin Receptor Family
}

\author{
Thomas Liebmann, ${ }^{1}$ Markus Kruusmägi, ${ }^{1}$ Nermin Sourial-Bassillious, ${ }^{1}$ Alexander Bondar, ${ }^{1,3}$ Per Svenningsson, ${ }^{2}$ \\ Marc Flajolet, ${ }^{4}$ Paul Greengard, ${ }^{4}$ Lena Scott, ${ }^{1}$ Hjalmar Brismar, ${ }^{1,5}$ and Anita Aperia ${ }^{1}$ \\ Departments of ${ }^{1}$ Women's and Children's Health and ${ }^{2}$ Clinical Neuroscience, Karolinska Institutet, 17177 Stockholm, Sweden, ${ }^{3}$ Institute of Chemical \\ Biology and Fundamental Medicine, 630090 Novosibirsk, Russia, ${ }^{4}$ Laboratory of Molecular and Cellular Neuroscience, The Rockefeller University, New \\ York, New York 10065, ${ }^{5}$ Science for Life Laboratory, Department of Applied Physics, Royal Institute of Technology, 17121 Solna, Sweden
}

Postsynaptic receptor trafficking plays an essential role in tuning neurotransmission and signal plasticity and has emerged as a potential therapeutic target in neuropsychiatric disease. Using a novel application of fluorescence recovery after photobleaching in rat hippocampal neurons, we examined transport from the soma to dendrites of seven G-protein-coupled receptors (GPCRs) implicated in mood disorders. Most GPCRs were delivered to dendrites via lateral diffusion, but one GPCR, the serotonin 1B receptor $\left(5-\mathrm{HT}_{1 \mathrm{~B}}\right)$, was delivered to the dendrites in secretory vesicles. Within the dendrites, $5-\mathrm{HT}_{1 \mathrm{~B}}$ were stored in a reservoir of accessible vesicles that were recruited to preferential sites in plasma membrane, as observed with superecliptic pHluorin labeling. After membrane recruitment, 5- $\mathrm{HT}_{1 \mathrm{~B}}$ transport via lateral diffusion and temporal confinement to inhibitory and excitatory synapses was monitored by single particle tracking. These results suggest an alternative mechanism for control of neuronal activity via a GPCR that has been implicated in mood regulation.

\section{Introduction}

Postsynaptic receptor trafficking has emerged as a major pathway for regulation of signal efficacy, specificity, and plasticity in neurons (Park et al., 2004; Heine et al., 2008; Makino and Malinow, 2009). Many recent studies have emphasized the importance of lateral diffusion as a major transport pathway for postsynaptic receptors (Serge et al., 2002; Triller and Choquet, 2003; Jacob et al., 2008). Recycling between the plasma membrane and the cytosol has been examined for most well characterized postsynaptic receptors. The determinants of postsynaptic receptor trafficking have become promising targets of neuropharmacological drugs (Beattie et al., 2010; Kristiansen et al., 2010; Thorsen et al., 2010).

Trafficking of postsynaptic G-protein-coupled receptors (GPCRs) has received relatively little attention despite their importance as drug targets and modulators of cell responses to external stimuli. Few GPCR trafficking studies have demonstrated translation or recycling processes in dendrites (Morinville et al., 2003; Arttamangkul et al., 2008; Ramírez et al., 2009), whereas a majority describe transport mechanics in cell lines or limited within neuronal cell bodies (Schmid et al.,

Received April 12, 2012; revised Aug. 27, 2012; accepted 0ct. 9, 2012.

Author contributions: T.L., P.G., L.S., H.B., and A.A. designed research; T.L., N.S.-B., and L.S. performed research; T.L., M.K., A.B., P.S., M.F., and H.B. contributed unpublished reagents/analytic tools; T.L. and M.K. analyzed data; T.L., M.K., and A.A. wrote the paper.

This work was supported by Swedish Research Council Grants 2007-4582 and 2010-3261, the Erling-Persson Family Foundation, the Märta and Gunnar V. Philipson Foundation, the Söderberg Foundation, and Department of Defense — United States Army Medical Research Acquisition Activity Grant W81XWH-09-1-0401.

Correspondence should be addressed to Anita Aperia at the above address. E-mail: Anita.Aperia@ki.se.

DOI:10.1523/JNEUROSCI.1804-12.2012

Copyright $\odot 2012$ the authors $\quad 0270-6474 / 12 / 3217998-11 \$ 15.00 / 0$
2008; Yu et al., 2009; Fichter et al., 2010). It is still unclear how GPCRs are transported into the dendrites. Most GPCRs are generally believed to translocate to the membrane via the unregulated, secretory pathway in the soma and are ultimately modulated through local sensitization and recycling in dendrites.

Advancements of imaging techniques such as photoactivatable (Patterson and Lippincott-Schwartz, 2002) and pH-sensitive (Miesenböck et al., 1998) proteins and quantum dot (Dahan et al., 2003) labeling allow selective imaging of discrete protein populations, vesicle exocytosis, and trafficking of individual protein molecules, respectively, in living neurons. Such tools provide insight into regulation mechanisms and will likely be instrumental for identifying novel modulators of postsynaptic receptor transport. In this study, we used these imaging techniques to investigate whether postsynaptic GPCRs involved in affective and schizoaffective disorders have a common means of incorporation into the diffusing membrane pool or whether there exist specialized trafficking routes. We examined the trafficking of seven GPCRs commonly implicated in schizophrenia and depression (Scott et al., 2006; Svenningsson et al., 2006; Navinés et al., 2008; Kruusmägi et al., 2009; Sourial-Bassillious et al., 2009; WarnerSchmidt et al., 2009; Glantz et al., 2010) from the soma to the dendritic tree by confocal microscopy and adaptation of fluorescence recovery after photobleaching (FRAP) (Jacobson et al., 1976). Dendrite delivery commonly occurred via plasma membrane lateral diffusion with the exception of the serotonin $1 \mathrm{~B}$ receptor $\left(5-\mathrm{HT}_{1 \mathrm{~B}}\right)$, which was transported from the soma to the dendrite in vesicle aggregates and delivered to the dendritic plasma membrane via exocytosis of these storage vesicles. The identification of a noncanonical postsynaptic transport route for 
GPCRs may open new opportunities for targeting receptor availability and activity.

\section{Materials and Methods}

Cell cultures and transfection. Hippocampal neurons were cultured from embryonic day 18 Sprague Dawley rat embryos. Hippocampi were removed and washed in HBSS with $20 \mathrm{~mm}$ HEPES (Sigma-Aldrich), followed by incubation in $0.25 \%$ trypsin for $10 \mathrm{~min}$ at $37^{\circ} \mathrm{C}$, and dissociated by pipetting in Minimum Essential Medium (MEM). Cells were seeded at a density of $\sim 5 \times 10^{4} / \mathrm{cm}^{2}$ onto glass coverslips coated overnight at $37^{\circ} \mathrm{C}$ with $80 \mu \mathrm{g} / \mathrm{ml}$ poly-DL-ornithine (Sigma-Aldrich). Seeding medium contained MEM with 10\% horse serum, 2 mM L-glutamine, and 1 mu sodium pyruvate (Sigma-Aldrich). After $3 \mathrm{~h}$, the medium was replaced with Neurobasal medium containing 2\% B27, 2 mM L-glutamine, and $1 \%$ penicillin/streptomycin (Sigma-Aldrich). Half the medium volume was changed twice per week and replaced with Neurobasal medium containing 2\% B27 and 1\% penicillin/streptomycin. HEK293 cells were cultured in DMEM with 2 mM L-glutamine, $1 \%$ nonessential amino acids, and $10 \%$ fetal bovine serum. All media components were from Invitrogen unless stated otherwise. Neurons were transfected after 12-14 d in culture with Lipofectamine 2000 (Invitrogen), and cell lines were transfected with ExGen 500 (Fermentas), all according to the manufacturer's recommendations. Transfected cells were imaged or analyzed between 24 and $48 \mathrm{~h}$ after transfection.

Immunolabeling. For endogenous immunolabeling, cells were washed briefly with HEPES-buffered saline (HBS). Cells were fixed by incubation in a $4 \%$ paraformaldehyde, $0.01 \mathrm{M} \mathrm{PBS}, \mathrm{pH} 7.4$, solution for $5 \mathrm{~min}$ at $4^{\circ} \mathrm{C}$ followed by $10 \mathrm{~min}$ at $20^{\circ} \mathrm{C}$. Endogenous $5-\mathrm{HT}_{1 \mathrm{~B}}$ immunolabeling was performed using a tyramide signal amplification immunohistochemical protocol as described by Stanić et al. (2009) with the following modifications: the primary antibody was anti-5- $\mathrm{HT}_{1 \mathrm{~B}}$ (1:8000; AbNova), the blocking time was $1 \mathrm{~h}$, the secondary antibody used was a goat antimouse/horseradish peroxidase-conjugated (1:500; Dako) antibody, the incubation time was $1 \mathrm{~h}$, the FITC conjugate was diluted 1:400, and glass coverslips were mounted using Immu-mount (Thermo Fisher Scientific). For live-cell surface labeling of $\mathrm{HA}-5-\mathrm{HT}_{1 \mathrm{~B}}$, transfected cells were incubated in HBS with a primary anti-hemagglutinin (HA) antibody (1:500; Invitrogen) for $10 \mathrm{~min}$ at $20^{\circ} \mathrm{C}$. Cells were washed briefly five times with HBS to remove excess antibodies and were imaged directly. For intracellular HA labeling, cells were fixed (as above), membrane permeated with $0.2 \%$ Triton X-100 (Sigma-Aldrich) for $10 \mathrm{~min}$ at room temperature, and stained as mentioned above for the anti-HA antibody.

Construct design. C-terminal labels were generated by PCR amplification of each receptor cDNA $\left(\mathrm{m} 5-\mathrm{HT}_{1 \mathrm{~B}}, \mathrm{~h} 5-\mathrm{HT}_{1 \mathrm{~A}}, \mathrm{~h} 5-\mathrm{HT}_{4}, \mathrm{rD}_{2}\right)$ and insertion into the pEGFP-N3 vector. EGFP was replaced with Venus, YPet, mCherry, TagBFP (Evrogen), or photoactivatable green fluorescent protein (PAGFP). $\mathrm{D}_{1}$ and $\mathrm{D}_{5}$ construct designs were reported previously (Scott et al., 2006; Kruusmägi et al., 2009). The HA-5-HT ${ }_{1 \mathrm{~B}}$ construct DNA was generated by inserting oligonucleotides coding for the HA tag (MYPYDVPDYA) at the $\mathrm{N}$ terminus of $5-\mathrm{HT}_{1 \mathrm{~B}}$. The superecliptic pHluorin (SEP)-5- $\mathrm{HT}_{1 \mathrm{~B}}$ construct DNA was generated by inserting the SEP coding sequence surrounded by flexible linkers (GGGGGS) into the third extracellular loop of 5- $\mathrm{HT}_{1 \mathrm{~B}}$ (between amino acids 338 and 339 ). To verify that $5-\mathrm{HT}_{1 \mathrm{~B}}$ fusion proteins did not alter normal expression or function of the receptor, terminally and internally tagged receptors were assessed for proper translocation and adenylyl cyclase inhibition, measured with a cAMP assay. [Fusion did not prevent receptor activation, and inhibition of forskolin (10 $\mu \mathrm{M}$ for $90 \mathrm{~s})$ induced cAMP production in cultured HEK cells. A specific 5-HT1B agonist (CP93129, $1 \mathrm{~mm}$ for $90 \mathrm{~s}$; Tocris) was used for receptor activation.] Clathrin and caveolin were generated by PCR amplification from cDNA and insertion into TagRFP-C and TagBFP-N vectors (Evrogen), respectively. TagRFPRab constructs were generated by RT-PCR amplification of each rat Rab cDNA followed by insertion into the pTagRFP-C vector (purchased from Evrogen). The RFP-Gephyrin construct was a gift from Dr. Antoine Triller (INSERM, Paris, France), and PAGFP was a gift from Dr. Jennifer Lippincott-Schwartz (NIH, Bethesda, MD). The mGluR5-Venus construct was provided by Dr. Hong Wang (The Rockefeller University, New York, NY). All generated constructs were confirmed by sequencing anal- ysis. Amplified DNA was purified with the endotoxin-free PureYield Plasmid MidiPrep System (Promega).

Cell imaging. Confocal imaging was performed on an inverted Zeiss LSM 510 microscope with $40 \times(1.2 \mathrm{NA}$, water $)$ or $63 \times(1.4 \mathrm{NA}$, oil $)$ objectives. Emission was induced with argon laser lines at 458, 488, and $514 \mathrm{~nm}$ for cyan, green, and yellow labels, respectively. TagRFP was excited by a $561 \mathrm{~nm}$ diode laser. PAGFP was photoactivated with a 405 $\mathrm{nm}$ diode laser at $100 \%$ and $150 \mu$ s pixel dwell time over 10 iterations. Single-particle tracking (SPT) experiments were performed on an inverted Zeiss Axiovert 200 with a $63 \times(1.4 \mathrm{NA}$, oil) objective equipped with an Andor iXon + 897 EMCCD camera and an HBO 100 arc lamp with 30\% illumination intensity. The QD-655-B filter set was used for quantum dots (QDs); the GFP-3035B filter set for GFP/SEP; BFP-ABasic for TagBFP; and excitation filter FF01-543/22, dichroic mirror FF562-DI03, and emission filter FF01-593/40 for RFP (all filters from Semrock). Cells were imaged during perfusion with HBS (in mM): 110 $\mathrm{NaCl}, 137 \mathrm{NaH}_{2} \mathrm{PO}_{4}, 84 \mathrm{NaHCO}_{3}, 10$ glucose, 20 HEPES (SigmaAldrich), $75 \mathrm{KCl}, 147 \mathrm{CaCl}_{2}$, and $203 \mathrm{MgCl}_{2}$ (Merck) at $\mathrm{pH} 7.4$ at $37^{\circ} \mathrm{C}$. High-potassium $\mathrm{HBS}$ solutions were made by replacing $50 \mathrm{~mm} \mathrm{NaCl}$ with an additional $50 \mathrm{~mm} \mathrm{KCl}$. Confocal images were analyzed and quantified with the ImageJ software (http://rsbweb.nih.gov/ij/). Surface plots were generated with the ImageJ surface plot analysis tool. Confocal scans and image sequences were processed with a median filter to minimize random background noise. To approximate the distribution of each receptor, we estimated the ratio of dendrite core intensity to plasma membrane-associated intensity ( $0.36 \mu \mathrm{m}$ from the membrane) for dendrite branches of $\sim 1 \mu \mathrm{m}$ thickness. Cluster densities were quantified after detecting local maxima in the dendritic lumen with intensity 2.5 times that of average foreground pixels. Association ratios were quantified by a minimum of $50 \%$ overlap of $5-\mathrm{HT}_{1 \mathrm{~B}}$ with the respective coexpressed proteins after setting thresholds for cluster isolation.

Fractionation. Hippocampal tissue was dissected from 40-d-old male Sprague Dawley rats after decapitation and immediately frozen on dry ice. The tissue was homogenized in 8 vol of homogenization buffer containing 300 mм sucrose, 25 mм imidazole, 1 mм EDTA (Sigma-Aldrich), and Complete protease inhibitors (Roche Diagnostics) at pH 7.2. Fractionation of the homogenized tissue, adapted from Dunah and Standaert (2001), was performed in three centrifugation steps: $1000 \times g$ for $10 \mathrm{~min}$ (discarding pellet); 17,000 $\times g$ for $30 \mathrm{~min}$ (pellet retained for membrane fraction); and 100,000 $\times g$ for $60 \mathrm{~min}$ (pellet and supernatant retained for vesicle and cytosol fractions, respectively). Twenty to forty micrograms of total protein from each fraction was resolved by SDS-PAGE, transferred onto polyvinylidene difluoride membranes, and blotted with anti$5-\mathrm{HT}_{1 \mathrm{~B}}$ (1:500; Imgenex), anti- $\mathrm{D}_{1}$ (1:500) reported previously (Brismar et al., 1998), and anti-NKA $\alpha 3$ (1:1000; Affinity Bioreagents) antibodies.

Immunoprecipitation. Hippocampal tissue was dissected from 40-dold Sprague Dawley rats and kept in ice-cold RIPA buffer containing 50 mм Tris $\mathrm{HCl}, \mathrm{pH}$ 7.4, $50 \mathrm{~mm} \mathrm{NaCl}, 1 \mathrm{~mm}$ EDTA, $0.5 \%$ sodium deoxycholate, $0.5 \%$ Nonidet P-40, and protease inhibitors (Roche Diagnostics). The tissue was homogenized and centrifuged at $9000 \times g$ for $20 \mathrm{~min}$ at $4^{\circ} \mathrm{C}$. Supernatant protein concentration was measured by DC protein assay (Bio-Rad). Tissue lysate was subject to immunoprecipitation as described previously (Khan et al., 2008). Antibodies used for precipitation were as follows: anti-Gephyrin (Synaptic Systems), anti-PSD-95 (Affinity Bioreagents), anti-Homer (Santa Cruz Biotechnology), and anti-5-HT ${ }_{1 \mathrm{~B}}$ [mouse (AbNova) and rabbit (Santa Cruz Biotechnology)]. Concentrations used for immunoblotting were 1:500 for anti-Gephyrin and anti-5- $\mathrm{HT}_{1 \mathrm{~B}}$.

Single-particle tracking. For SPT experiments, dissociated neurons were cultured at a density of $1.05 \times 10^{4} / \mathrm{cm}^{2}$. Cells were transfected with $5-\mathrm{HT}_{1 \mathrm{~B}}$-SEP, PSD-95-BFP, and RFP-gephyrin at days 20 and 21 in culture with Lipofectamine 2000 . After $48 \mathrm{~h}$, coverslips were washed once with HBS and incubated with biotin-conjugated anti-GFP antibodies $(0.2 \mathrm{ng} / \mathrm{ml}$; Rockland Immunochemicals) for $5 \mathrm{~min}$ in HBS. After three brief washes with HBS, cells were incubated with QD655 streptavidinconjugated quantum dots (0.5 $\mathrm{nm}$ [SCAP]; Invitrogen) for $1 \mathrm{~min}$ in QD binding buffer (Bannai et al., 2006). Cells were then washed briefly 10 times with HBS and immediately imaged up to $30 \mathrm{~min}$ after completion of labeling. After acquiring synaptic images, QD images were recorded 
with a frequency of $20 \mathrm{~Hz}$ for $50 \mathrm{~s}$. All labeling, washing, and recording steps were performed at $37^{\circ} \mathrm{C}$. Custom Matlab software was used to identify and trace the QDs. Subpixel accuracy ( $\sim 10-20 \mathrm{~nm}$ resolution) was achieved by fitting a two-dimensional Gaussian function to each identified QD in every image frame (Gelles et al., 1988). Mean square displacement (MSD) curves were calculated from the particle trajectories (Saxton and Jacobson, 1997). Trajectories with $<30$ positions were rejected. Synaptic regions were defined as circular regions with a radius of $250 \mathrm{~nm}$, centered on a synaptic cluster. Initial diffusion coefficients were calculated by fitting a straight line to points 2 through 5 (interval, 50-200 $\mathrm{ms}$ ) of the MSD curve (Bannai et al., 2006). Cumulative frequency distributions were calculated from the individual diffusion coefficients.

Statistics. Statistical significance of paired differences for small samples or discontinuous data was verified by a nonparametric Wilcoxon signedrank test. Significant differences between three or more groups was verified by one-way ANOVA, followed by a post hoc multiple comparison with a Bonferroni correction. Significance for two normally distributed groups was verified by the two-tailed $t$ test. Data presented in boxplots represent median value, $25-75 \%$ inner quartile range, and minimum to maximum range (whiskers).

\section{Results}

Diverse pathways for GPCR transport from soma to dendrites Seven GPCRs [the dopamine 1 receptor $\left(D_{1}\right)$, the dopamine 2 receptor $\left(D_{2}\right)$, the dopamine 5 receptor $\left(D_{5}\right)$, the serotonin $1 \mathrm{~A}$ receptor $\left(5-\mathrm{HT}_{1 \mathrm{~A}}\right), 5-\mathrm{HT}_{1 \mathrm{~B}}$, the serotonin 4 receptor $\left(5-\mathrm{HT}_{4}\right)$, and the metabotropic glutamate type 5 receptor (mGluR5)] have been examined for their ability to transport in the dendrites either via lateral diffusion in the plasma membrane (Fig. 1A, orange path) or in vesicles within the dendritic lumen (Fig. $1 A$, green path). We first assessed transport of fluorescently labeled receptors by recording FRAP in dendritic branches of cultured hippocampal neurons (Fig. 1A, blue box). This method is well suited for the documentation of diffusion, and the geometry of the dendrite makes them particularly well suited for FRAP studies. FRAP recordings are presented as kymographs, each generated with a 3 pixel line width along the middle of the dendrite (Fig. 1B). All GPCRs were transported by diffusion in the plasma membrane, seen as a gradual fluorescence recovery after bleaching. An advantage of kymograph representation of FRAP recordings is simultaneous visualization of membrane diffusion and transport of receptor clusters, the latter appearing as slanted lines on the kymograph. FRAP recordings of $\mathrm{D}_{1}, \mathrm{D}_{2}, \mathrm{D}_{5}, 5-\mathrm{HT}_{1 \mathrm{~A}}, 5-\mathrm{HT}_{4}$, and mGluR5 resulted in little or no detectable cluster movement. In contrast, the 5- $\mathrm{HT}_{1 \mathrm{~B}}$ FRAP recordings showed a combination of membrane diffusion and transport in dense intracellular clusters (Fig. $1 B$, white arrows), compatible with vesicular trafficking. Analysis of the FRAP intensity curves supported the notion that $5-\mathrm{HT}_{1 \mathrm{~B}}$, in contrast to the other GPCRs studied, is also, to a large extent, transported via an intracellular route (Fig. $1 C$ ).

We next examined whether the intracellular $5-\mathrm{HT}_{1 \mathrm{~B}}$ clusters in dendrites had been delivered from the soma by performing time-lapse recordings at the soma/dendrite junction (Fig. $1 A$, red box). Kymographs of time-lapse recordings revealed that the dendritic $5-\mathrm{HT}_{1 \mathrm{~B}}$ clusters were delivered from the soma (Fig. $1 D$, white arrows). Recordings of the other six GPCRs showed little or no cluster export from soma to dendrite. For additional evidence that the dendritic $5-\mathrm{HT}_{1 \mathrm{~B}}$ is delivered from the soma in intracellular clusters, we labeled the receptor with PAGFP (Patterson and Lippincott-Schwartz, 2002). After photoactivation of 5- $\mathrm{HT}_{1 \mathrm{~B}}$ in the soma, we detected transport of discrete receptor clusters in the dendrites (Fig. 1E).

\section{Storage of 5-HT ${ }_{1 \mathrm{~B}}$ in intracellular dendritic reservoirs}

The dendritic expression of fluorescent $\mathrm{D}_{1}, \mathrm{D}_{2}, \mathrm{D}_{5}, 5-\mathrm{HT}_{1 \mathrm{~A}}$, $5-\mathrm{HT}_{1 \mathrm{~B}}$, and mGluR5 is shown in representative dendrite images (Fig. 2A). $\mathrm{D}_{1}, \mathrm{D}_{2}, \mathrm{D}_{5}, 5-\mathrm{HT}_{1 \mathrm{~A}}, 5-\mathrm{HT}_{4}$ and mGluR5 displayed high intensity localized to the plasma membrane, whereas $5-\mathrm{HT}_{1 \mathrm{~B}}$ was localized extensively in clusters throughout the dendrites. The cytosol-to-membrane ratio of $5-\mathrm{HT}_{1 \mathrm{~B}}(0.76)$ was at least $50 \%$ greater than all other receptors (Fig. 2B, light gray). Quantification of intracellular cluster density also showed a distinct difference between $5-\mathrm{HT}_{1 \mathrm{~B}}$ and the other GPCRs (Fig. $2 \mathrm{~B}$, dark gray). The $5-\mathrm{HT}_{1 \mathrm{~B}}$ cluster density $(20.7 \pm 1.0 / 100 \mu \mathrm{m}$, mean $\pm \mathrm{SEM})$ was at least 7 times greater than densities of all other examined receptors. Sporadic membrane-associated clusters were seen with $\mathrm{D}_{1}, \mathrm{D}_{2}, \mathrm{D}_{5}, 5-\mathrm{HT}_{1 \mathrm{~A}}, 5-\mathrm{HT}_{4}$, and mGluR5, likely attributed to receptor confinement at the postsynaptic density (Scott et al., 2006; Renner et al., 2010).

Each estimate of the $5-\mathrm{HT}_{1 \mathrm{~B}}$ cytosol-to-membrane ratio is likely an underestimate as a considerable number of clusters are transported near the surface of the plasma membrane. To more accurately measure the receptor distribution, we generated an expression system with $5-\mathrm{HT}_{1 \mathrm{~B}}$ tagged with $\mathrm{pH}$-sensitive SEP. Expression of SEP in the vesicle lumen results in fluorochrome quenching (no fluorescence) attributable to the acidic environment (Miesenböck et al., 1998; Burrone et al., 2006). Exocytosis changes the SEP environment from the acidic vesicle lumen to a more neutral extracellular environment, thereby enabling fluorescence of membrane-inserted receptors. By comparing surface expression of $5-\mathrm{HT}_{1 \mathrm{~B}}$-SEP with fluorescence of alkalinized vesicles, we directly measured a cytosol-to-membrane ratio of $2.0 \pm$ 0.2 (mean \pm SEM) in dendrites of cultured neurons (Fig. $2 C$ ).

The appearance of the $5-\mathrm{HT}_{1 \mathrm{~B}}$ clusters is suggestive of vesicular expression, but to rule out expression artifacts, a series of control experiments were carried out. To address a possible artifact caused by overexpression of exogenous receptors, we considered the variation of expression levels within individual neurons. No significant difference in expression pattern was seen between neurons with low and high expression of fluorescently labeled $5-\mathrm{HT}_{1 \mathrm{~B}}$ (Fig. 2D,E). Vesicle-like expression and trafficking of $5-\mathrm{HT}_{1 \mathrm{~B}}$ was seen as early as $5 \mathrm{~h}$ after transfection, also supporting the conclusion that $5-\mathrm{HT}_{1 \mathrm{~B}}$ clusters are not an artifact of overexpression. The dendritic appearance of fluorescently labeled $5-\mathrm{HT}_{1 \mathrm{~B}}$ was also compared with endogenous 5- $\mathrm{HT}_{1 \mathrm{~B}}$ immunolabeling. After membrane permeabilization, clustered immunoreactivity was seen in the dendritic lumen (Fig. $2 F$ ). Endogenous receptor clusters were similar to expressed fluorescent receptors, both in cytosol-to-membrane ratio $(0.8 \pm 0.03$, mean \pm SEM $)$ and receptor cluster density $(18.3 \pm 1.1 / 100 \mu \mathrm{m}$, mean $\pm \mathrm{SEM})$.

To confirm that fusion of a fluorescent protein to $5-\mathrm{HT}_{1 \mathrm{~B}}$ did not disrupt normal trafficking, we expressed the receptor with a small HA tag at the $\mathrm{N}$ terminus. Surface labeling without membrane permeabilization resulted in diffuse immunoreactivity without dendritic clusters (Fig. 2G). Immunolabeling after permeabilization resulted in an intracellular cluster density of $22.4 \pm$ $3.8 / 100 \mu \mathrm{m}$ (mean \pm SEM) (Fig. $2 H$ ), similar to fluorescent protein labeling and endogenous expression. Fractionation of adult hippocampal tissue provided further evidence for a predominant vesicular expression of $5-\mathrm{HT}_{1 \mathrm{~B}}$ as compared with the more membranous distribution of $\mathrm{D}_{1}$ (Fig. $2 I$ ) and a reference protein principally found in the plasma membrane, $\mathrm{Na}, \mathrm{K}$ ATPase $\alpha 3$. Together, these observations suggest that $5-\mathrm{HT}_{1 \mathrm{~B}}$ are abundantly expressed in intracellular vesicular complexes in agreement with previous ultrastructural results (Peddie et al., 2008, 2010). 
A

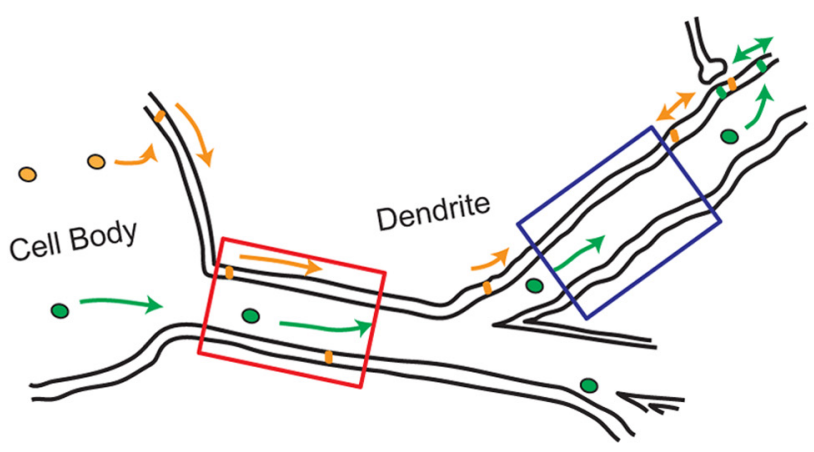

C

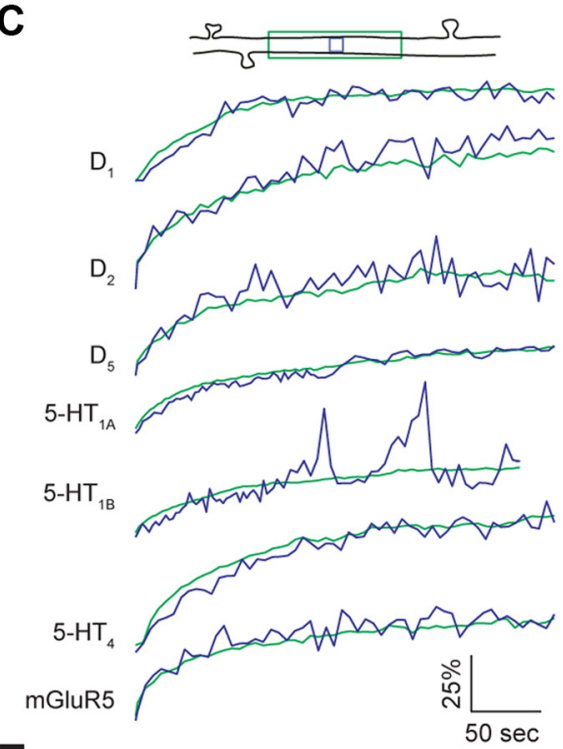

E

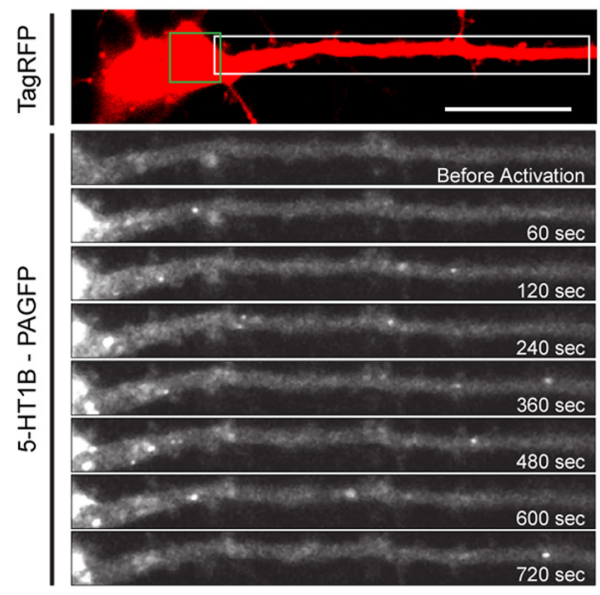

D

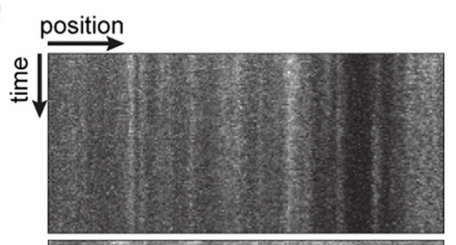

$\mathrm{D}_{1}$
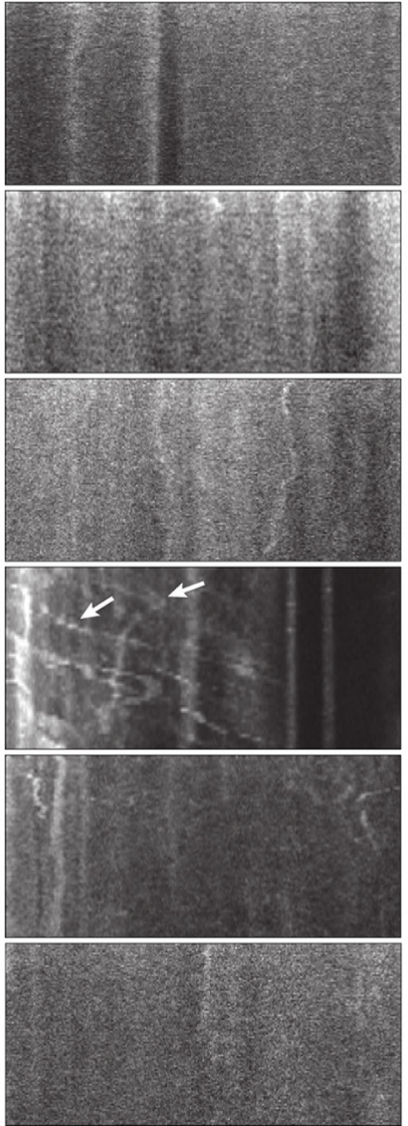

$\mathrm{D}_{5}$
B

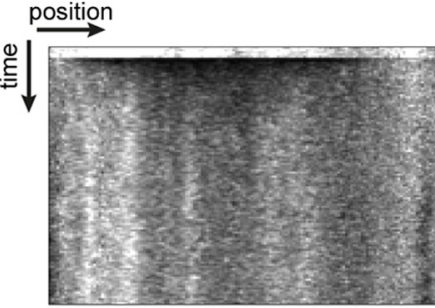

$\mathrm{D}_{1}$

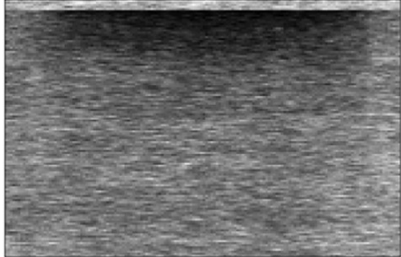

$\mathrm{D}_{2}$

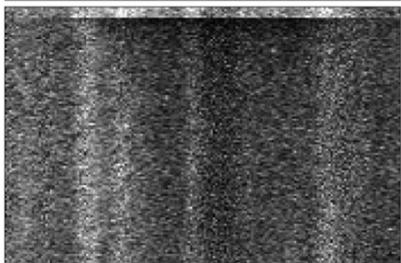

$\mathrm{D}_{5}$

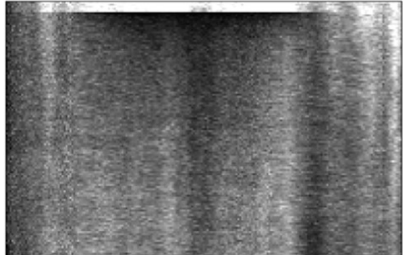

$5-\mathrm{HT}_{1 \mathrm{~A}}$

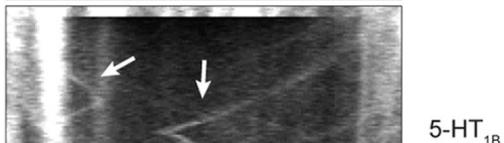

$5-\mathrm{HT}_{4}$

mGluR5

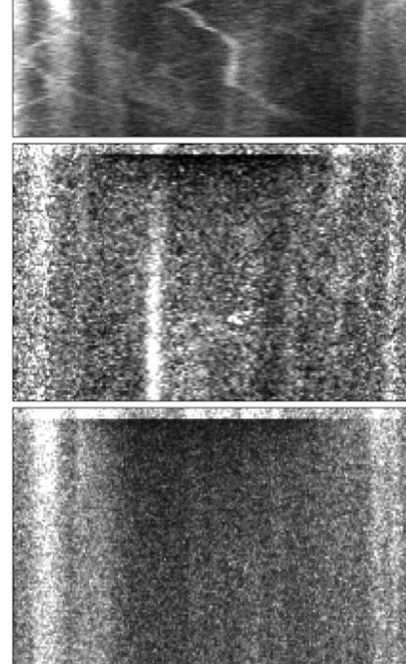

$5-\mathrm{HT}_{1 \mathrm{~B}}$

Figure 1. Two routes exist for GPCR transport from the soma to dendrites. $A$, Schematic diagram of two possible paths from the soma to dendrites. The orange path shows membrane insertion at the soma followed by diffusion in the plasma membrane to dendrites. The green path shows vesicle delivery from the soma to dendrites and subsequent exocytosis at the dendritic membrane. $\boldsymbol{B}$, Kymographs showing FRAP recordings of a dendrite fragment of a primary hippocampal neuron ( $\boldsymbol{A}$, blue box) for the indicated fluorescently labeled GPCRs. The kymographs represent $300 \mathrm{~s}$ recordings of $20 \mu \mathrm{m}$ dendrite fragments (10 $\mu \mathrm{m}$ bleached) with an acquisition frequency of $0.4 \mathrm{~Hz}$. Note the transport of $5-\mathrm{HT}_{1 \mathrm{~B}}$ in discrete clusters. $\mathrm{C}$, Intensity curves of representative FRAP recordings. The curves represent recovery of the entire $10 \mu \mathrm{m}$ bleached region (green box in diagram) and a localized $1 \mu \mathrm{m}$ region within the bleached dendritic shaft (blue box in diagram). Intensity peaks in the blue $5-\mathrm{HT}_{1 B}$ curve result from vesicle transport through the recorded region. $\boldsymbol{D}$, Kymographs of time-lapse recordings of $30 \mu \mathrm{m}$ regions at the soma/dendrite juncture $(\boldsymbol{A}$, red box). Scans were acquired at $1 \mathrm{~Hz}$. for $100 \mathrm{~s}$. Note the anterograde trafficking of $5-\mathrm{HT}_{1 \mathrm{~B}}$ Clusters from the soma (left, outside of margin) to the dendrite. $\boldsymbol{E}$, Transport of 5-HT ${ }_{1 B}-P^{-}$AGFP from the soma to dendrite. The neuron is filled with TagRFP. The green box denotes the photoactivated area of the soma. The white rectangle was magnified on the right panel at different times. Scale bar, $20 \mu \mathrm{m}$.

Active transport of dendritic $5-\mathrm{HT}_{1 \mathrm{~B}}$ in secretory vesicles Results from the above FRAP and photoactivation experiments suggest that the mobile intracellular $5-\mathrm{HT}_{1 \mathrm{~B}}$ clusters are vesicular complexes. To identify types of vesicles transporting $5-\mathrm{HT}_{1 \mathrm{~B}}$, we compared localization of $5-\mathrm{HT}_{1 \mathrm{~B}}$ clusters with multiple vesicle markers from the Ras-related family of accessory proteins (Stenmark and Olkkonen, 2001). We detected only a moderate association with Rab4a, Rab5a, and Rab1la (average of $22 \%$ ), three 


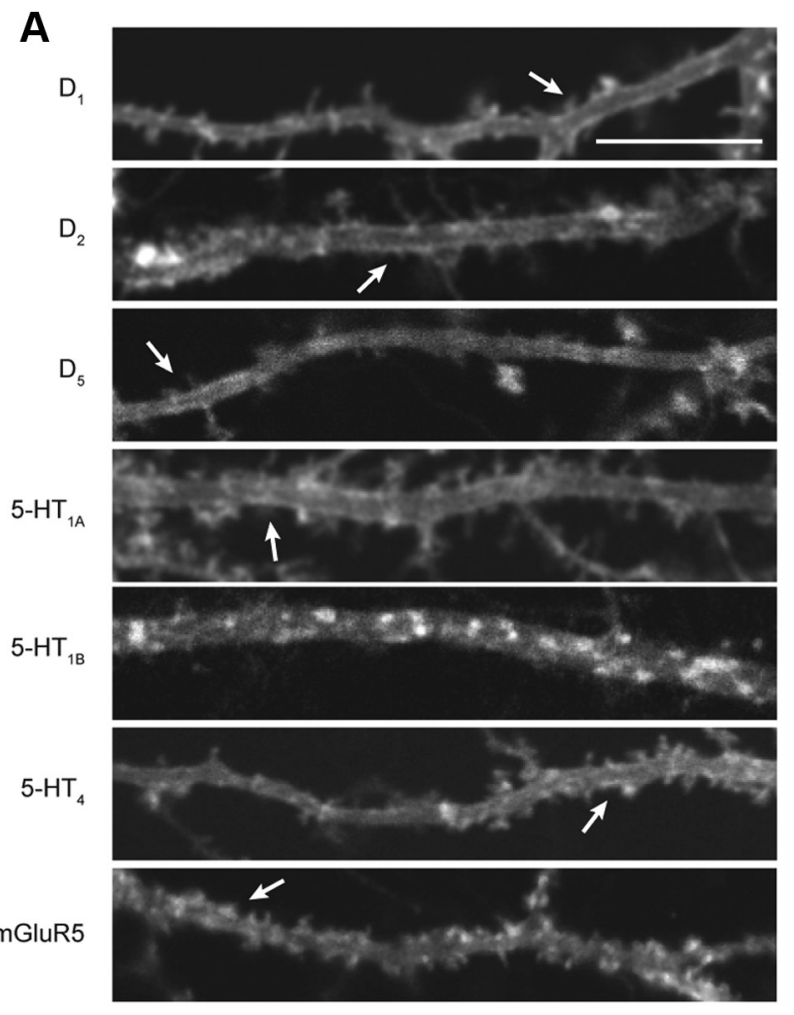

B

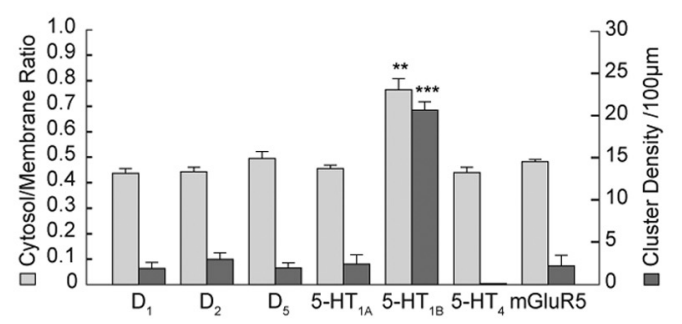

C
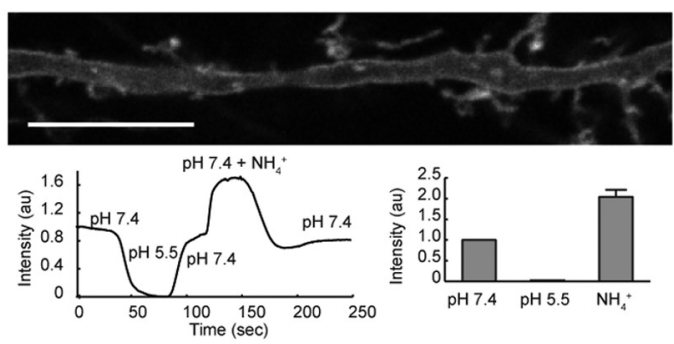

D

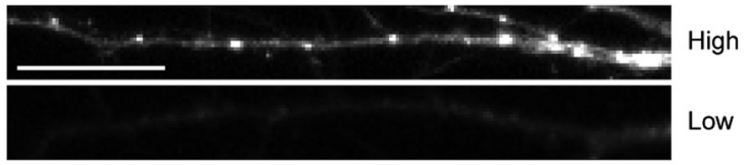

E

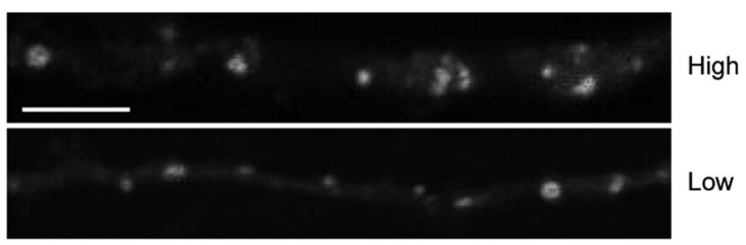

F

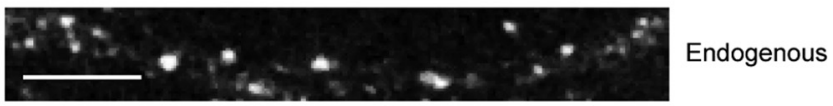

G

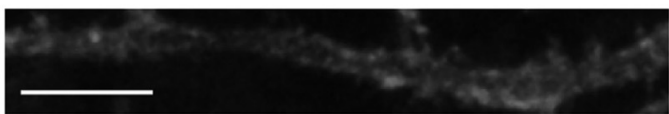

HA-tagged surface

H

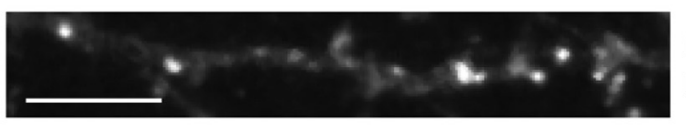

Ha-tagged permeabilized

I

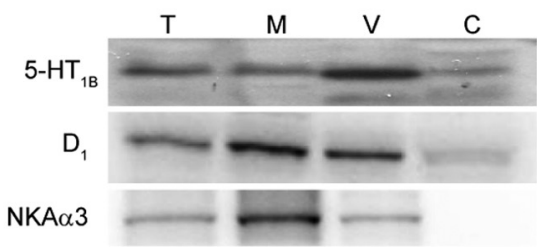

Figure 2. $5-\mathrm{HT}_{1 \mathrm{~B}}$ resides in the dendrite lumen of hippocampal neurons, whereas other GPCRs are more abundant in the plasma membrane. $\boldsymbol{A}$, Magnified confocal scan of dendrite fragments with fluorescent labeling of indicated GPCRs. High membrane expression (white arrows) is seen for all receptors except for $5-\mathrm{HT}_{1 \mathrm{~B}}$. Clusters seen with $\mathrm{D}_{1}, \mathrm{D}_{2}, \mathrm{D}_{5}, 5-\mathrm{HT}_{1 \mathrm{~A}}, 5-\mathrm{HT}_{4}$, and mGluR5 are membrane associated and in spine-like protrusions. Scale bar, $10 \mu \mathrm{m}$. B, Quantification of cytosol to membrane ratio (light gray bars) and cluster density (dark gray bars) ( $n=$ minimum of 6 dendrites). $\boldsymbol{C}$, Confocal image of $5-\mathrm{HT}_{1 \mathrm{~B}}$-SEP expression in dendrites and quantification of response to $\mathrm{pH}$ changes. A concentration of $40 \mathrm{~mm} \mathrm{NH}_{4} \mathrm{Cl}$ in HBS was used to alkalinize vesicles and enable fluorescence of eclipsed molecules. Quantification is relative intensity (mean $\pm \mathrm{SEM} ; n=7$ dendrites from 3 different cultures). Scale bar, $10 \mu \mathrm{m}$. $D$, Images of dendritic 5 - $\mathrm{HT}_{1 B}$ in cells expressing high (top) and low (bottom) total fluorescence. Detection settings are identical between cell scans. Scale bar, $20 \mu \mathrm{m}$. $\boldsymbol{E}$, Optimized scan settings for each expression level show no significant difference between

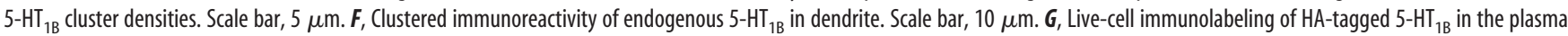
membrane. Scale bar, $10 \mu \mathrm{m} . \boldsymbol{H}$, Immunolabeling of $\mathrm{HA}$-tagged $5-\mathrm{HT}_{1 \mathrm{~B}}$ in dendrite after permeabilization. Note the presence of pronounced clusters. Scale bar, $5 \mu \mathrm{m}$. $\boldsymbol{I}$, Subcellular fractionation of $5-\mathrm{HT}_{1 \mathrm{~B}}$ and $\mathrm{D}_{1}$ from 40 - $\mathrm{d}$-old rat hippocampi. The catalytic $\alpha 3$ subunit of the sodium-potassium pump was used as a plasma membrane marker. $\mathrm{T}$, total fraction; $\mathrm{M}$, membrane fraction; $\mathrm{V}$, vesicle fraction; C, cytosol fraction. ${ }^{* *} p<0.01 ;{ }^{* *} p<0.001$.

accessory proteins involved in endocytic and recycling processes; and a prominent association with Rab8a (44\%), an accessory protein involved in trafficking of nascent proteins in vesicles from the Golgi apparatus to the plasma membrane (Fig. $3 A-F$ ). This suggests that a majority of the $5-\mathrm{HT}_{1 \mathrm{~B}}$ complexes represent Golgi-derived secretory vesicles compared with the small fraction representing recycling or degradation-bound vesicles. 5- $\mathrm{HT}_{1 \mathrm{~B}}$ did not associate significantly with clathrin light chain (7\%) but considerably colocalized with caveolin (39\%) (Fig. 3G), revealing a caveolin-dependent turnover balancing the secretory release (Pearse, 1976; Rothberg et al., 1992).

The observed variation of vesicle sizes (Fig. $3 A-F$ ) prompted an investigation of possible aggregated vesicular complexes. We selected an oblong vesicle $\sim 1.1 \mu \mathrm{m}$ in length (full-width halfmaximum) and assessed receptor diffusion within the cluster. One edge of the cluster was bleached (Fig. $3 H$, blue box), and intensity profiles were monitored for the bleached region and a region at the opposing end of the cluster (Fig. $3 H$, red box). Intensity profile curves reveal that there is no significant exchange of receptors within the cluster (Fig. $3 \mathrm{H}$, bottom plot), confirming the presence of multivesicular bodies or vesicular complexes. In control conditions, frequency of vesicles transported through a $10 \mu \mathrm{m}$ fragment was $11.0 \pm 1.2 / 100 \mathrm{~s}$ (mean $\pm \mathrm{SEM}$ ), and maximum cluster velocity was estimated at $0.92 \pm 0.07 \mu \mathrm{m} / \mathrm{s}$ (mean \pm SEM), as measured from kymograph trajectory slopes of 15 dendrites. 
A

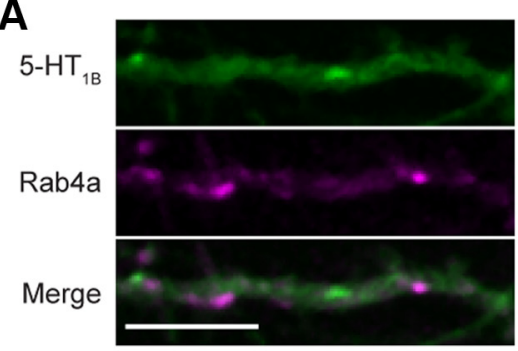

C

$5-\mathrm{HT}_{1 \mathrm{~B}}$

Rab11a

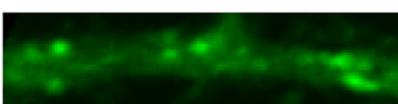

Merge

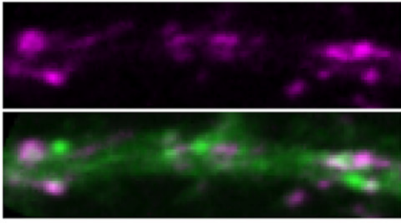

E

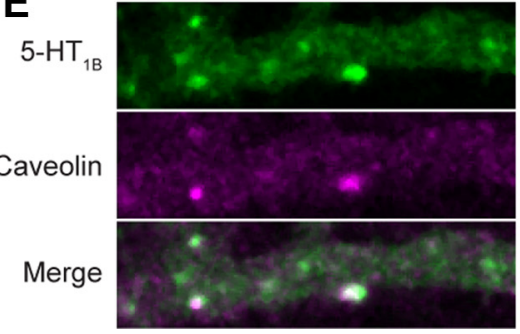

B

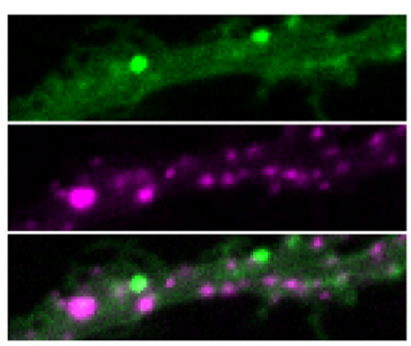

D

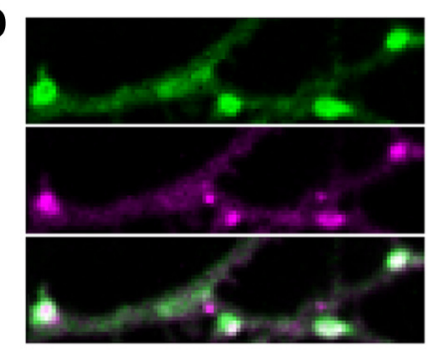

F

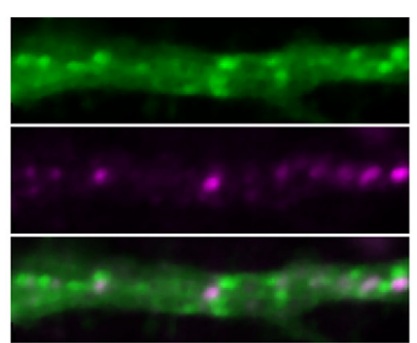

G
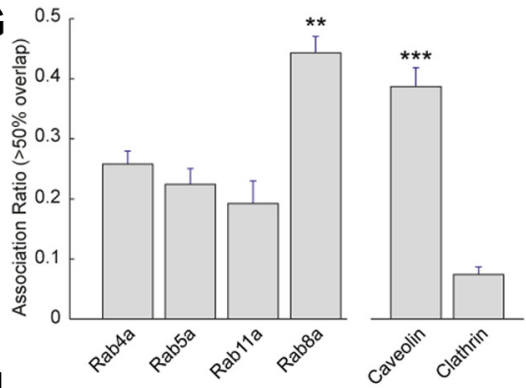

$5-\mathrm{HT}_{1 \mathrm{~B}}$
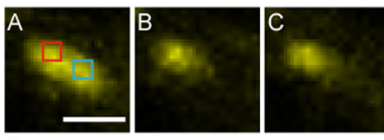

Rab8a

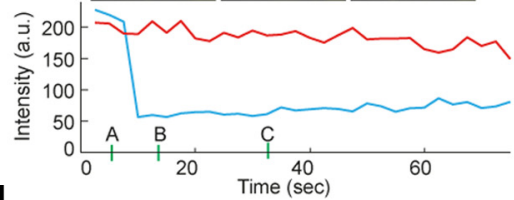

$5-\mathrm{HT}_{1 \mathrm{~B}}$

Clathrin

Merge

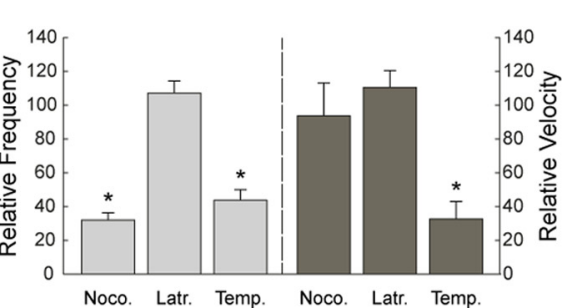

Figure 3. $5-\mathrm{HT}_{1 \mathrm{~B}}$ are actively transported in secretory vesicles in dendritic branches. $A-F$, Images of dendrite fragments expressing $5-\mathrm{HT}_{1 \mathrm{~B}}$ ( $g$ reen) and each indicated vesicle marker (red). $\mathrm{Scale}$ bar, $5 \mu \mathrm{m}$. G, Association ratio (ratio of 5-HT1b vesicles with $>50 \%$ marker overlap) for 5- $\mathrm{HT}_{1 \mathrm{~B}}$ and Rab4a, Rab5a, Rab11a, Rab8a, caveolin, and clathrin, respectively ( $n=$ minimum of 9 dendrites). The highest association was found between $5-\mathrm{HT}_{1 \mathrm{~B}}$ and a secretory vesicle marker, Rab8a. $\mathrm{H}, 5-\mathrm{HT}_{1 \mathrm{~B}}$ is expressed in multivesicular complexes. A 5- $\mathrm{HT}_{1 \mathrm{~B}}$ Cluster was partially bleached (blue box), and the intensity profile was monitored for $75 \mathrm{~s}$ for the bleached region and region on the opposing side (red box) of the cluster. Scale bar, $1 \mu \mathrm{m}$. Images A, B, and ( represent before bleaching, directly after bleaching, and $30 \mathrm{~s}$ after bleaching, respectively. Intensity profiles show no notable exchange from the unbleached half of the vesicular cluster to the bleached half. $I$, The number of mobile vesicles is sensitive to nocodazole and temperature, but not latrunculin $A$. The maximum velocity of vesicle transport is sensitive only to temperature. Quantification of relative frequency (light gray bars) and relative maximum velocity (dark gray bars) of moving vesicle clusters. Bar plot gives average paired ratio of measured values (posttreatment/pretreatment) for each respective treatment $\left(n=4\right.$ dendrites for each treatment). ${ }^{*} p<0.05 ;{ }^{* *} p<0.01 ;{ }^{* * *} p<0.001$.

To further elucidate the mechanism of transport for dendritic $5-\mathrm{HT}_{1 \mathrm{~B}}$ in vesicles, we examined sensitivity to disrupted polymerization of transport filaments. Disruption of microtubule polymerization with nocodazole was found to fragment the trafficking of discrete 5- $\mathrm{HT}_{1 \mathrm{~B}}$ clusters (Fig. $3 I$ ). In contrast, actin disruption with latrunculin A had no significant effect on $5-\mathrm{HT}_{1 \mathrm{~B}}$ trafficking (Fig. 3I). We found that transport of the $5-\mathrm{HT}_{1 \mathrm{~B}}$ clusters in dendrites was highly dependent on temperature (Fig. 3I). The number of transported clusters was reduced after nocodazole treatment and temperature reduction to 32 and $44 \%$ of control, respectively (Fig. 3I, light gray). The average maximum velocity of moving vesicles was not affected by nocodazole or latrunculin A, but temperature reduction retarded the speed to $\sim 32 \%$ of control (Fig. $3 I$, dark gray).

Recruitment of dendritic $5-\mathrm{HT}_{1 \mathrm{~B}}$ to the plasma membrane The finding that $5-\mathrm{HT}_{1 \mathrm{~B}}$ are retained in intracellular vesicles and that only a fraction is diffusing in the plasma membrane indicates that the functionality of postsynaptic $5-\mathrm{HT}_{1 \mathrm{~B}}$ is critically dependent on the regulated delivery to the plasma membrane from vesicle stores. To study the regulation of stored receptors and investigate the interaction between vesicles and the plasma membrane, we used $5-\mathrm{HT}_{1 \mathrm{~B}}$ tagged with $\mathrm{pH}$ sensitive SEP as a marker for vesicle fusion. To monitor deliv- ery of $5-\mathrm{HT}_{1 \mathrm{~B}}$ from vesicle stores to the plasma membrane, we performed time-lapse recordings on dendrites of neurons expressing $5-\mathrm{HT}_{1 \mathrm{~B}}-\mathrm{SEP}$. Exocytosis of vesicles containing $5-\mathrm{HT}_{1 \mathrm{~B}}-\mathrm{SEP}$ was characterized as an instantaneous increase of local fluorescence greater than three times the mean membrane intensity followed by subsequent intensity decay (Fig. $4 A)$. Infrequent prolonged exocytotic events with peak intensities sustained for $>1 \mathrm{~s}$ before decay were discarded. The time course of 5- $\mathrm{HT}_{1 \mathrm{~B}}$ exocytosis was recorded as fluorescence decay after vesicle fusion with the plasma membrane. The mean fluorescence profile shows an abrupt increase in fluorescence intensity followed by a rapid decay with a half-time of $640 \mathrm{~ms}$ (Fig. 4B). Fluorescence loss indicates that receptors leave the fusion site, which can occur either by lateral diffusion or immediate internalization. Surface plots of single exocytotic events show the initially confined fluorescence at the docking site (Fig. 4C). Each subsequent plot shows spreading of receptors into the surrounding membrane, suggesting lateral diffusion as a means of dispersion.

For evidence of receptor diffusion from the docking site to the surrounding membrane, we mapped each $5-\mathrm{HT}_{1 \mathrm{~B}}-\mathrm{SEP}$ exocytotic event with two regions, one defining the initial event area and the other defining the surrounding area (three times the initial area). The total integrated intensity profile of the inner region from one exocytotic event showed an abrupt 
A
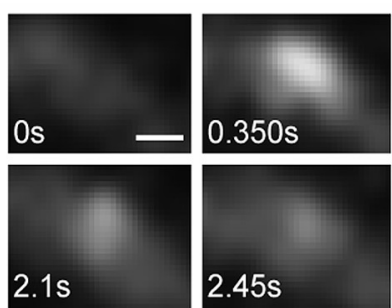
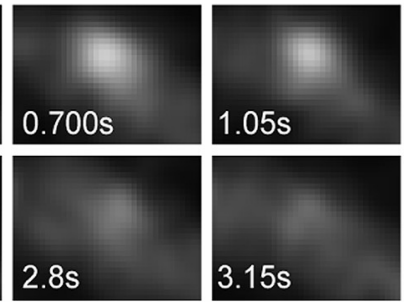
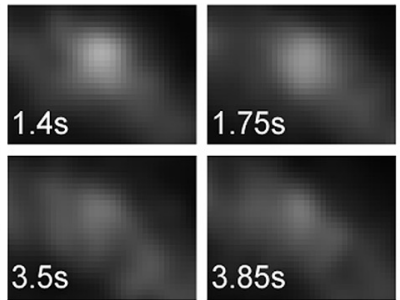

B
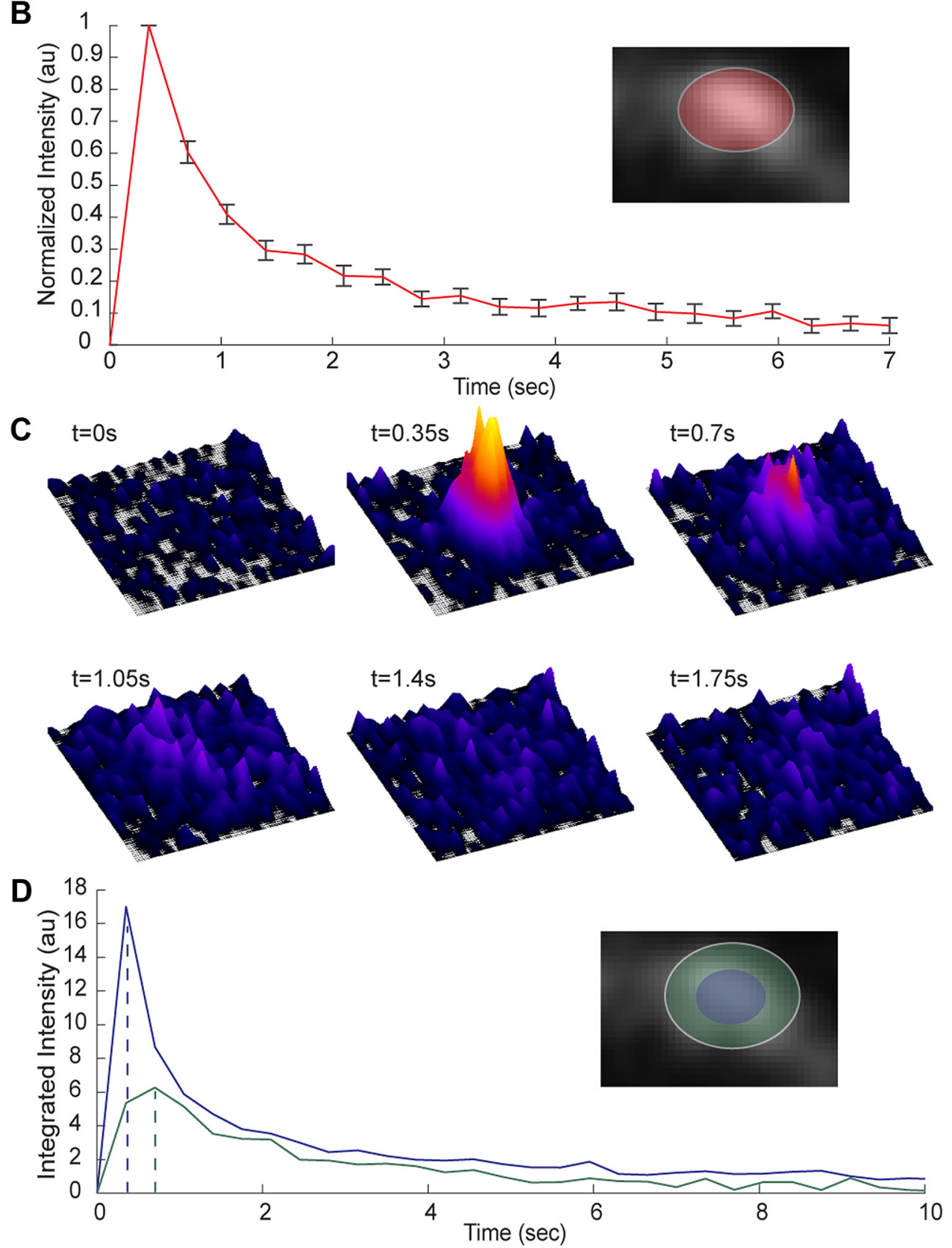

Figure 4. Vesicular $5-\mathrm{HT}_{1 \mathrm{~B}}$ are recruited to the dendritic plasma membrane. $A$, Time series of superediptic pHlluorin-labeled $5-\mathrm{HT}_{1 \mathrm{~B}}\left(5-\mathrm{HT}_{1 \mathrm{~B}}-\mathrm{SEP}\right)$ exocytosis in the dendrite of a cultured hippocampal neuron. Scale bar, $1 \mu \mathrm{m}$. $\boldsymbol{B}$, Intensity profile of $5-\mathrm{HT}_{1 \mathrm{~B}}$-SEP exocytosis. The curve represents the intensity median \pm SEM of normalized events $(n=32)$. A sample recording region is indicated in the image inset. $\boldsymbol{C}$, Intensity surface plot of $5-\mathrm{HT}_{1 \mathrm{~B}}$-SEP exocytosis. The $3 \mathrm{D}$ plot indicates intensity distribution of $5-\mathrm{HT}_{1 \mathrm{~B}}$-SEP during exocytosis. During vesicle docking, receptors are confined to the incorporation site. Progressive scans show depletion of receptors at the docking site and increased intensity in the surrounding membrane (compared with initial level). $\boldsymbol{D}$, Lateral diffusion of $5-\mathrm{HT}_{1 \mathrm{~B}}$-SEP. Blue and green curves represent inner and perimeter regions, respectively, of an exocytotic event, as seen in the example image insert. Note the time delay between the curve peaks. Peak times are indicated with dashed vertical lines.

increase in fluorescence, indicating vesicle docking, immediately followed by an exponential-like decay until it settled at a level slightly above the initial intensity (Fig. $4 D$, blue curve). The intensity profile of the surrounding area also increased during a fusion event (Fig. $4 D$, green curve), but there is a time difference between intensity peaks of the two regions (Fig. 4D, dashed lines), most likely caused by passive diffusion of $5-\mathrm{HT}_{1 \mathrm{~B}}$ away from the site of exocytosis (inner area). 
A

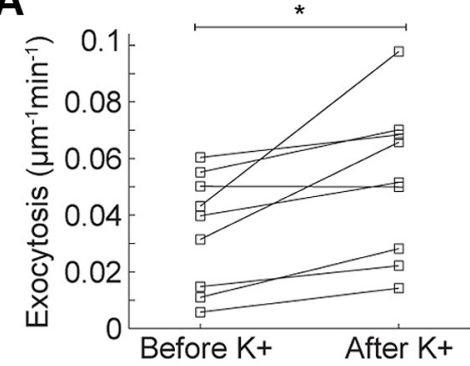

B

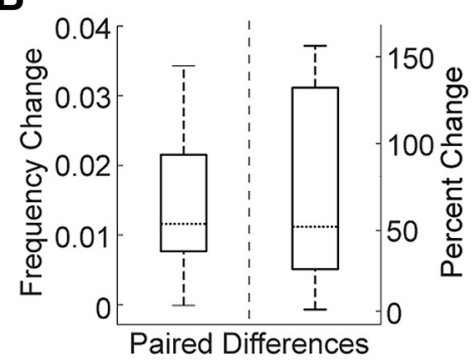

C

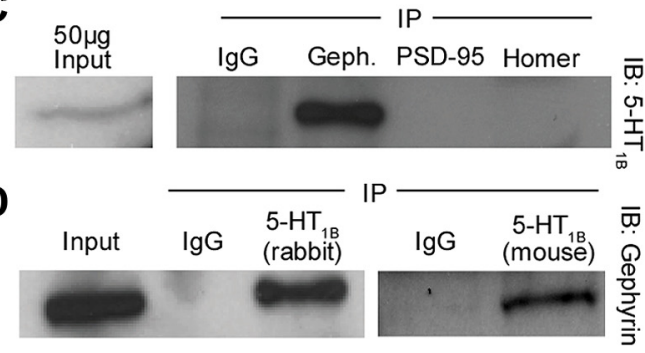

E

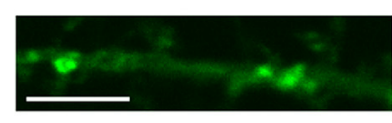

$5-\mathrm{HT}_{1 \mathrm{~B}}$

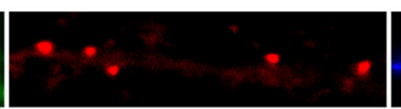

Gephyrin

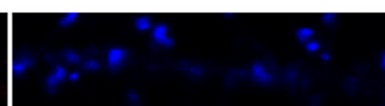

PSD-95

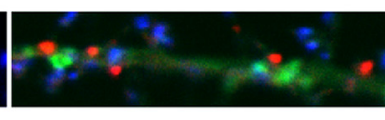

Merge
F

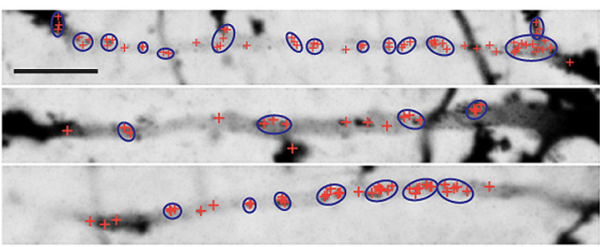

G

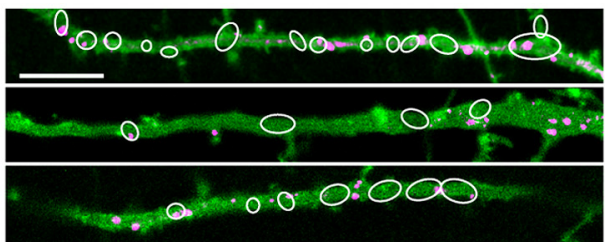

$\mathrm{H}$

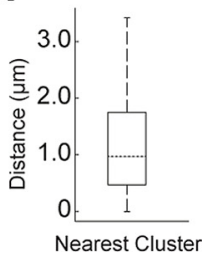

Figure 5. $5-\mathrm{HT}_{1 \mathrm{~B}}$ recruitment occurs at preferential extrasynaptic sites and is increased with $\mathrm{K}^{+}$stimulation. $A, 5-\mathrm{HT}_{1 \mathrm{~B}}-\mathrm{SEP}$ exocytosis increased for eight of nine recorded cells after stimulation with elevated potassium ( $50 \mathrm{~mm} \mathrm{~K}^{+}$for $30 \mathrm{~s}$ ). $\boldsymbol{B}$, The event frequency increase was $0.012 \pm 0.005 \mu \mathrm{m}^{-1} \mathrm{~min}^{-1}$ (median $\pm \mathrm{SEM}$ ) or $49 \%$ of prestimulation frequency. $\boldsymbol{C}$, Immunoprecipitation shows an interaction between $5-\mathrm{HT}_{1 \mathrm{~B}}$ and gephyrin. No interaction was detected between $5-\mathrm{HT}_{1 \mathrm{~B}}$ and PSD-95 or Homer. Antibodies against each synaptic molecule were used to precipitate the protein complexes. $\boldsymbol{D}$, The precipitation sequence was reversed using two different $5-\mathrm{TH}_{1 \mathrm{~B}}$ antibodies to confirm an interaction between $5-\mathrm{HT}_{1 \mathrm{~B}}$ and gephyrin. $\boldsymbol{E}$, Fluorescent expression of 5 - $\mathrm{HT}_{1 \mathrm{~B}}$ compared with inhibitory (gephyrin) and excitatory (PSD-95) synapse markers. Scale bar, $5 \mu \mathrm{m} \boldsymbol{F}$, Preferential sites of exocytosis. Maximum projections of 5-HT ${ }_{1 B}$-SEP depicting exocytosis in dendrites over $10 \mathrm{~min}$ recordings. Exocytotic events are designated with pluses $(n=334)$. Blue rings encircle events occurring within one typical event diameter $(1 \mu \mathrm{m})$ from an additional occurrence. A total of $78 \pm 3 \%$ (mean \pm SEM) of events was found in preferential regions. Recording frequency was $2.0 \mathrm{~Hz}$. Scale bar, $10 \mu \mathrm{m}$. G, Exocytosis occurs outside of inhibitory synapses. The image shows expression of 5- $\mathrm{HT}_{1 \mathrm{~B}}$-SEP (green) and gephyrin (red) in hippocampal dendrites. Preferential exocytosis sites indicated with white circles overlap $\sim 45 \%$ with gephyrin clusters. Scale bar, $10 \mu \mathrm{m}$. $\boldsymbol{H}$, Proximity of recruitment sites to inhibitory synapses. A boxplot of center-to-center distance between preferential recruitment sites and nearest gephyrin cluster ( $n=44)$ is shown. The measured distance of $1.00 \pm 0.17 \mu \mathrm{m}$ (median \pm SEM) suggests extrasynaptic recruitment. ${ }^{*} p<0.05$.

$5-\mathrm{HT}_{1 \mathrm{~B}}$ recruitment is sensitive to membrane depolarization Next we examined receptor recruitment in response to increased synaptic activity. In cultured neurons, we induced action potential firing and neurotransmitter release by depolarizing the neuronal membrane with elevated extracellular $\mathrm{K}^{+}$concentration (Wenthold, 1979) for $30 \mathrm{~s}$. Stimulation increased 5-HT ${ }_{1 \mathrm{~B}}-\mathrm{SEP}$ recruitment to the plasma membrane. Eight of the nine recordings showed an increase in exocytotic event frequency (Fig. 5A). The paired frequency difference after stimulation was increased $0.012 \pm 0.005 \mu \mathrm{m}^{-1} \mathrm{~min}^{-1}$ (median $\pm \mathrm{SEM}$ ), corresponding to a $49 \%$ increase (Fig. 5B).

\section{$5-\mathrm{HT}_{1 \mathrm{~B}}$ are recruited to preferential extrasynaptic sites}

To associate the response to increased activity with a synaptic signaling domain, we looked for an interaction between 5- $\mathrm{HT}_{1 \mathrm{~B}}$ and synaptic scaffold proteins. Using coimmunoprecipitation studies on tissue homogenates from adult rat hippocampi, we detected an interaction between $5-\mathrm{HT}_{1 \mathrm{~B}}$ and gephyrin, the major scaffolding molecule at inhibitory synapses (Choquet and Triller, 2003) (Fig. 5C,D). On the contrary, we found no interaction between 5- $\mathrm{HT}_{1 \mathrm{~B}}$ and PSD-95 or Homer, the major neuronal excitatory scaffolding proteins (Choquet and Triller, 2003) (Fig. $5 C$ ). We additionally examined localization of $5-\mathrm{HT}_{1 \mathrm{~B}}$ clusters in relation to both inhibitory and excitatory synaptic sites. 5-HT1B clusters were not located at either excitatory or inhibitory synapses (Fig. 5E).

Because spatial organization of proteins in the dendrites is a major determinant of cellular function, we explored the idea of preferential exocytosis at in the dendritic membrane. Recurring exocytosis is expected at presynaptic terminals (Gaffield et al., 2009), but little is known about sites of preferential exocytosis in the dendritic membrane. Time-lapse recordings of $5-\mathrm{HT}_{1 \mathrm{~B}}-\mathrm{SEP}$ show the extent of spatial proximity of $5-\mathrm{HT}_{1 \mathrm{~B}}$-SEP exocytotic events (Fig. $5 F$ ). We detected that $78 \pm 3 \%$ (mean \pm SEM) of recorded exocytotic events in each neuron correspond to regions of repeated exocytosis, indicating a probable recognition mechanism at these sites for vesicles containing $5-\mathrm{HT}_{1 \mathrm{~B}}$.

To determine whether gephyrin indicates a preferential site of $5-\mathrm{HT}_{1 \mathrm{~B}}$ exocytosis, we expressed fluorescent RFP-gephyrin together with $5-\mathrm{HT}_{1 \mathrm{~B}}-\mathrm{SEP}$. The representative images show both RFP-gephyrin expression and regions of preferential exocytosis (Fig. $5 G$ ). We found that $45 \pm 6 \%$ (mean \pm SEM) of preferential sites of $5-\mathrm{HT}_{1 \mathrm{~B}}-\mathrm{SEP}$ recruitment overlap with gephyrin clusters. Nearest-neighbor distance analysis revealed that preferential recruitment sites are $1.00 \pm 0.17 \mu \mathrm{m}$ (median \pm SEM) from the closest gephyrin cluster (Fig. 5H). Proximity to excitatory synapses was not estimated as exocytosis was not detected in spines or protrusions from the dendrite shaft.

\section{5-HT ${ }_{1 \mathrm{~B}}$ diffuses in the plasma membrane to}

inhibitory synapses

Since $5-\mathrm{HT}_{1 \mathrm{~B}}$ are frequently recruited to the extrasynaptic membrane, synaptic integration requires trafficking of the receptors to sites of synaptic activity. To monitor receptor trafficking dynamics in the dendritic membrane, we labeled $5-\mathrm{HT}_{1 \mathrm{~B}}$ with quantum dots and tracked individual receptor molecules with high tempo- 
A

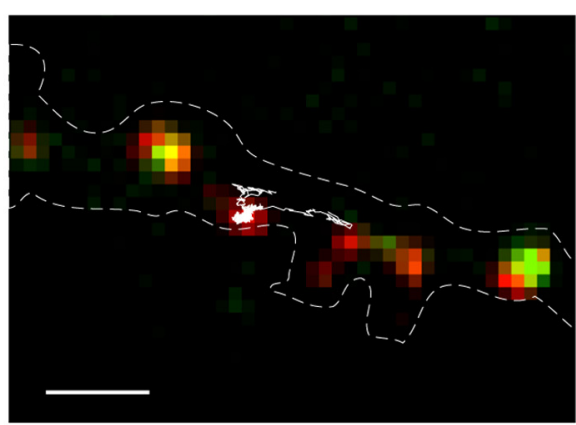

D

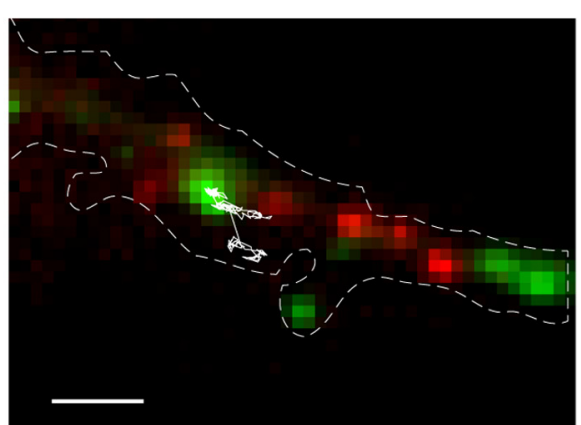

G

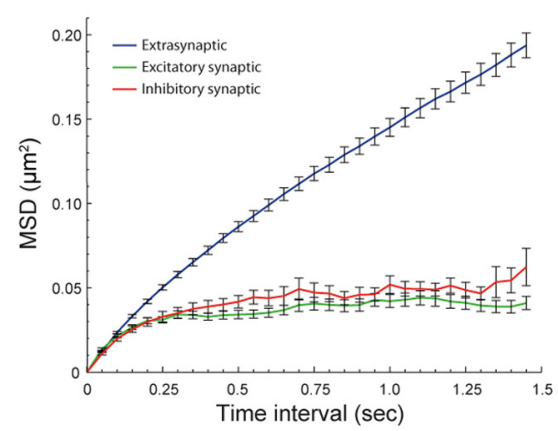

B

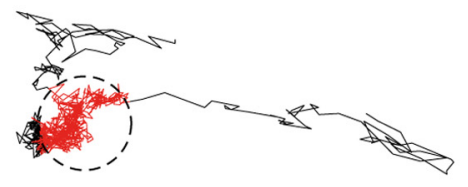

E

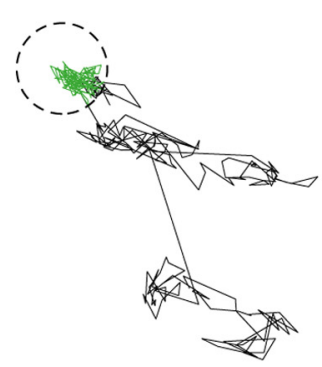

H

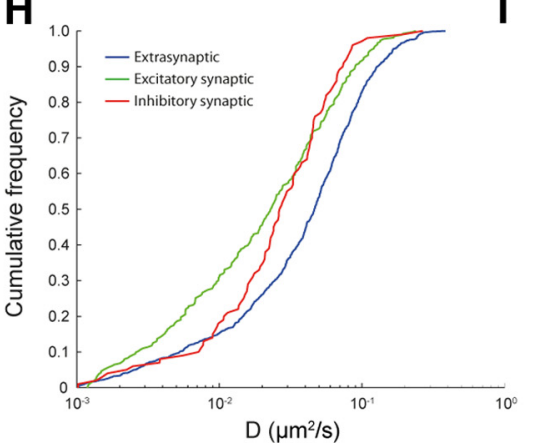

$\mathbf{F}$
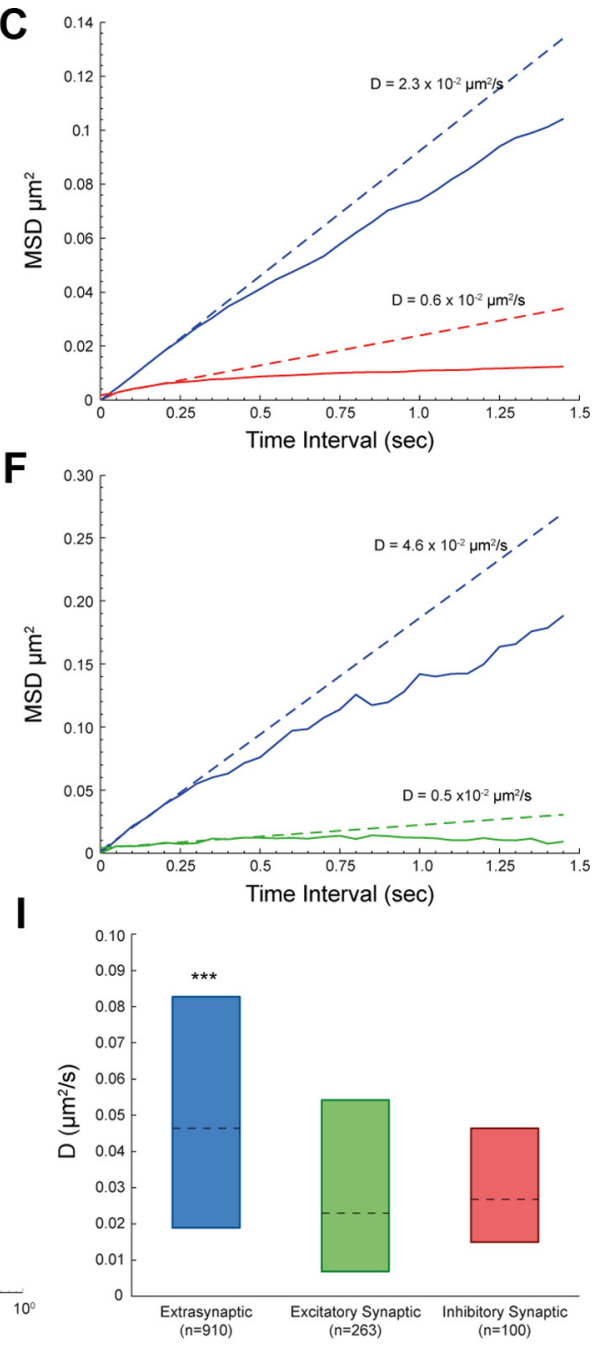

Figure 6. The lateral diffusion of $5-\mathrm{HT}_{1 \mathrm{~B}}$ is slowed at synapses. $\boldsymbol{A}$, Dendrite trace of cultured neuron transfected with $5-\mathrm{HT} \mathrm{TB}_{1 \mathrm{~S}} \mathrm{SEP}$ (not shown) and gephyrin (red) and PSD-95 (green). A single $5-\mathrm{HT}_{1 \mathrm{~B}}$ trajectory is shown with a solid white line. Scale bar, $2 \mu \mathrm{m}$. $\boldsymbol{B}$, Isolated trajectory from $\boldsymbol{A}$ with the associated inhibitory synaptic region outlined as a circle. The trajectory within the synaptic cluster is in red. C, MSD curves calculated from extrasynaptic (blue) and inhibitory synaptic (red) regions of the trajectory shown in $\boldsymbol{A}$ and $\boldsymbol{B}$. 5 - $\mathrm{HT}_{1 \mathrm{~B}}$ movement is restricted in the inhibitory synaptic

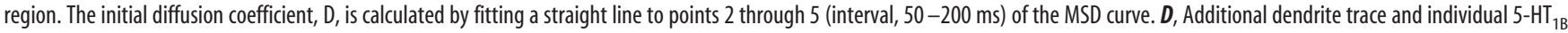
trajectory (as in $A$ ). $\boldsymbol{E}$, Isolated trajectory from $\boldsymbol{D}$ with an associated excitatory synaptic region (as in $\boldsymbol{B}$ ). $\boldsymbol{F}$, Extrasynaptic (blue) and excitatory synaptic (green) MSD curves from the trajectory in $\boldsymbol{D}$ and $\boldsymbol{E}$, calculated as described for $\boldsymbol{C}$. G, Average MSD curves for all experimental trajectories in extrasynaptic membrane and synaptic regions. MSD curves from inhibitory and excitatory synaptic regions reveal more restricted movement, as inferred from the increased negative deflection from the initial slope of the MSD curve. $\boldsymbol{H}$, Cumulative frequency distribution plots of average initial diffusion coefficients of extrasynaptic membrane and synaptic regions. $I$, Boxplot of average initial diffusion coefficients for extrasynaptic membrane and synaptic regions. ${ }^{* *} p<0.001$.

ral resolution $(50 \mathrm{~ms})$ and spatial resolution $(<15 \mathrm{~nm})$ (Dahan et al., 2003; Renner et al., 2009). SPT of 5- $\mathrm{HT}_{1 \mathrm{~B}}$ reinforced the FRAP results that demonstrate lateral diffusion of receptors in the dendritic membrane. Measurements of $5-\mathrm{HT}_{1 \mathrm{~B}}$ diffusion within different compartments of the dendritic membrane were achieved by simultaneously labeling inhibitory and excitatory synapses with fluorescent gephyrin and PSD-95, respectively. We found that $5-\mathrm{HT}_{1 \mathrm{~B}}$ is in lateral diffusion in extrasynaptic and synaptic membrane. MSD curves of individual recordings reveal a shift from free diffusion in the extrasynaptic membrane to a more confined motion and reduced diffusion in both inhibitory and excitatory synaptic regions (Fig. 6A-F). Average MSD curves from all recordings also describe two distinct modes of characteristic motion. In the extrasynaptic membrane, $5-\mathrm{HT}_{1 \mathrm{~B}}$ movement closely resembles free diffusion, whereas reduced diffusion and confinement is seen in synaptic regions (Fig. 6G). From MSD curves we can also estimate receptor diffusion coefficients within each membrane region (Fig. $6 H, I$ ). 5- $\mathrm{HT}_{1 \mathrm{~B}}$ explored the extra- synaptic membrane with an initial diffusion constant of $4.6 \pm$ $0.2 \times 10^{-2} \mu \mathrm{m}^{2} / \mathrm{s}$ (median $\pm \mathrm{SEM}$ ). At the inhibitory and excitatory synaptic membranes, the diffusion coefficient was reduced to $2.7 \pm 0.4 \times 10^{-2} \mu \mathrm{m}^{2} / \mathrm{s}$ and $2.3 \pm 0.3 \times 10^{-2} \mu \mathrm{m}^{2} / \mathrm{s}$ (median \pm SEM), respectively.

\section{Discussion}

Trafficking of postsynaptic receptors is a means of regulating synaptic function in the dendrites, yet the details of delivery processes are not well explored. In this study, we present two general pathways for receptor transport to synaptic sites in the dendrite. Six of the seven GPCRs examined notably preferred passive diffusion from the cell body to the dendrite branches. This energy efficient transport via the plasma membrane is likely shared by most postsynaptic GPCRs. An alternate pathway, as seen with $5-\mathrm{HT}_{1 \mathrm{~B}}$, retains receptors in transport vesicles. At the cost of expending energy on active transport, $5-\mathrm{HT}_{1 \mathrm{~B}}$ is maintained as a readily accessible source of mobile receptors for rapid exocytotic 
recruitment to the membrane throughout the dendrites. Though unique among the receptors included in our study, this active trafficking pathway may be used by yet unexamined receptors.

Previous postsynaptic GPCR studies describing intracellular trafficking are mostly limited to receptor recycling or constitutive transport of nascent proteins in cell lines or neuron cell bodies (Arttamangkul et al., 2008; Schmid et al., 2008; Yu et al., 2009; Fichter et al., 2010). The present results describe a noncanonical transport pathway for $5-\mathrm{HT}_{1 \mathrm{~B}}$ that differs from all other receptors examined in this study. Additional GPCRs well described by nonconstitutive trafficking in dendrites include the $\mathrm{GABA}_{\mathrm{B}}$ and opioid receptors. $\mathrm{GABA}_{\mathrm{B}}$ monomers are retained in the endoplasmic reticulum in dendrites and require oligomerization before membrane delivery (Ramírez et al., 2009). Localization studies of delta opioid receptors in dendrites also demonstrate endoplasmic reticulum retention, possibly regulated by receptor folding (Wang and Pickel, 2001; Morinville et al., 2003) and transport in dense core vesicles (Wang et al., 2010). However, it remains to be seen whether these receptors are transported long distances from the soma to dendrites as shown here with $5-\mathrm{HT}_{1 \mathrm{~B}}$.

Our results show that vesicles carrying $5-\mathrm{HT}_{1 \mathrm{~B}}$ throughout the dendrites do not colocalize with synaptic sites. However, immunoprecipitation between $5-\mathrm{HT}_{1 \mathrm{~B}}$ and gephyrin, but not with PSD-95 or Homer, does suggests involvement in inhibitory signaling in the postsynaptic membrane, consistent with the inhibitory role of presynaptic $5-\mathrm{HT}_{1 \mathrm{~B}}$ autoreceptors and heteroreceptors in axons (Sari, 2004). These results also suggest that the interaction with gephyrin occurs in the postsynaptic membrane, similar to reports of other postsynaptic receptors interacting with synaptic scaffold molecules (Calamai et al., 2009). Though we have yet to identify an interacting protein at excitatory synapses, our single molecule diffusion data demonstrates that $5-\mathrm{HT}_{1 \mathrm{~B}}$ are slowed both at inhibitory and excitatory synapses, each a potential site of 5-HT neurotransmission.

To study the process by which vesicular $5-\mathrm{HT}_{1 \mathrm{~B}}$ are delivered to the membrane, we expressed SEP-labeled receptors. SEP has previously been used to assess the exocytosis of recycled receptors by measuring fluorescence accumulation over long time periods (Makino and Malinow, 2009; Petrini et al., 2009) and resolving single exocytotic events that suggest membrane incorporation (Yudowski et al., 2006). Using two-dimensional intensity analysis, we demonstrate a lateral spread of multiple receptors from the exocytotic site to the surrounding membrane. This observation supports the notion that each vesicle delivers multiple $5-\mathrm{HT}_{1 \mathrm{~B}}$ copies to the membrane. As described for other receptor types (e.g., AMPA receptors) (Makino and Malinow, 2009), 5- $\mathrm{HT}_{1 \mathrm{~B}}$ exocytose in close proximity to inhibitory synaptic sites and are dependent on lateral diffusion for delivery to the signaling platform at the synapse. Nearly all recorded exocytotic events occurred in dendrite branches, not in protruding spines where excitatory synapses are located.

Recruitment of nascent $5-\mathrm{HT}_{1 \mathrm{~B}}$ was indistinguishable from exocytosis of recycling vesicles. We can postulate, based on the considerable overlap with Golgi-derived secretory vesicle accessory proteins compared with the reduced overlap with recycling vesicle markers, that a bulk of the recruitment events occur with nascent, nonrecycled receptors. Many cell-line studies have demonstrated that $5-\mathrm{HT}_{1 \mathrm{~B}}$ can be regulated via internalization (Janoshazi et al., 2007; Chen et al., 2009), and we suggest here that $5-\mathrm{HT}_{1 \mathrm{~B}}$ can be internalized in dendrites, but no clear description of $5-\mathrm{HT}_{1 \mathrm{~B}}$ exocytosis via recycling processes in dendrites has been presented. It remains to be shown the extent that recycling contributes to the diffusing pool in the dendritic plasma membrane.

Importantly, the details of 5- $\mathrm{HT}_{1 \mathrm{~B}}$ trafficking set this receptor apart from many other postsynaptic GPCRs involved in neuropsychiatric disorders. The vesicle trafficking described here distinguishes $5-\mathrm{HT}_{1 \mathrm{~B}}$ from $5-\mathrm{HT}_{1 \mathrm{~A}}$ and $5-\mathrm{HT}_{4}$, all of which are $5-\mathrm{HT}$ receptors implicated in mood disorders (Navinés et al., 2008; Warner-Schmidt et al., 2009). Dysfunctional 5-HT regulation is a major cause of depression (Meltzer, 1989), and in many cases, treatment with selective serotonin reuptake inhibitors (SSRIs) is used as an efficient antidepressive therapy. However, there are cases where SSRIs are inefficient or should not be used. These cases include very severe depression or with adolescent patients, where SSRIs are known to cause severe side effects (Scahill et al., 2005). A probable cause of such side effects is the indiscriminate activation of all 5-HT receptors at the synapse. This detailed description of the $5-\mathrm{HT}_{1 \mathrm{~B}}$ distribution and anterograde trafficking opens a new avenue for a receptor-specific regulation of 5-HT signaling.

\section{References}

Arttamangkul S, Quillinan N, Low MJ, von Zastrow M, Pintar J, Williams JT (2008) Differential activation and trafficking of micro-opioid receptors in brain slices. Mol Pharmacol 74:972-979. CrossRef Medline

Bannai H, Lévi S, Schweizer C, Dahan M, Triller A (2006) Imaging the lateral diffusion of membrane molecules with quantum dots. Nat Protoc 1:2628-2634. CrossRef Medline

Beattie MS, Ferguson AR, Bresnahan JC (2010) AMPA-receptor trafficking and injury-induced cell death. Eur J Neurosci 32:290-297. CrossRef Medline

Brismar H, Asghar M, Carey RM, Greengard P, Aperia A (1998) Dopamineinduced recruitment of dopamine D1 receptors to the plasma membrane. Proc Natl Acad Sci U S A 95:5573-5578. CrossRef Medline

Burrone J, Li Z, Murthy VN (2006) Studying vesicle cycling in presynaptic terminals using the genetically encoded probe synaptopHluorin. Nat Protoc 1:2970-2978. CrossRef Medline

Calamai M, Specht CG, Heller J, Alcor D, Machado P, Vannier C, Triller A (2009) Gephyrin oligomerization controls GlyR mobility and synaptic clustering. J Neurosci 29:7639-7648. CrossRef Medline

Chen L, Salinas GD, Li X (2009) Regulation of serotonin 1B receptor by glycogen synthase kinase-3. Mol Pharmacol 76:1150-1161. CrossRef Medline

Choquet D, Triller A (2003) The role of receptor diffusion in the organization of the postsynaptic membrane. Nat Rev Neurosci 4:251-265. CrossRef Medline

Dahan M, Lévi S, Luccardini C, Rostaing P, Riveau B, Triller A (2003) Diffusion dynamics of glycine receptors revealed by single-quantum dot tracking. Science 302:442-445. CrossRef Medline

Dunah AW, Standaert DG (2001) Dopamine D1 receptor-dependent trafficking of striatal NMDA glutamate receptors to the postsynaptic membrane. J Neurosci 21:5546-5558. Medline

Fichter KM, Flajolet M, Greengard P, Vu TQ (2010) Kinetics of G-proteincoupled receptor endosomal trafficking pathways revealed by single quantum dots. Proc Natl Acad Sci U S A 107:18658-18663. CrossRef Medline

Gaffield MA, Tabares L, Betz WJ (2009) Preferred sites of exocytosis and endocytosis colocalize during high- but not lower-frequency stimulation in mouse motor nerve terminals. J Neurosci 29:15308-15316. CrossRef Medline

Gelles J, Schnapp BJ, Sheetz MP (1988) Tracking kinesin-driven movements with nanometre-scale precision. Nature 331:450-453. CrossRef Medline

Glantz LA, Gilmore JH, Overstreet DH, Salimi K, Lieberman JA, Jarskog LF (2010) Pro-apoptotic Par-4 and dopamine D2 receptor in temporal cortex in schizophrenia, bipolar disorder and major depression. Schizophr Res 118:292-299. CrossRef Medline

Heine M, Groc L, Frischknecht R, Beique JC, Lounis B, Rumbaugh G, Huganir RL, Cognet L, Choquet D (2008) Surface mobility of postsynaptic AMPARs tunes synaptic transmission. Science 320:201-205. CrossRef Medline 
Jacob TC, Moss SJ, Jurd R (2008) GABA(A) receptor trafficking and its role in the dynamic modulation of neuronal inhibition. Nat Rev Neurosci 9:331-343. CrossRef Medline

Jacobson K, Derzko Z, Wu ES, Hou Y, Poste G (1976) Measurement of the lateral mobility of cell surface components in single, living cells by fluorescence recovery after photobleaching. J Supramol Struct 5:565(417)576(428). CrossRef Medline

Janoshazi A, Deraet M, Callebert J, Setola V, Guenther S, Saubamea B, Manivet P, Launay JM, Maroteaux L (2007) Modified receptor internalization upon coexpression of 5-HT1B receptor and 5-HT2B receptors. Mol Pharmacol 71:1463-1474. CrossRef Medline

Khan F, Spicarová Z, Zelenin S, Holtbäck U, Scott L, Aperia A (2008) Negative reciprocity between angiotensin II type 1 and dopamine D1 receptors in rat renal proximal tubule cells. Am J Physiol Renal Physiol 295: F1110-F1116. CrossRef Medline

Kristiansen LV, Bakir B, Haroutunian V, Meador-Woodruff JH (2010) Expression of the NR2B-NMDA receptor trafficking complex in prefrontal cortex from a group of elderly patients with schizophrenia. Schizophr Res 119:198-209. CrossRef Medline

Kruusmägi M, Kumar S, Zelenin S, Brismar H, Aperia A, Scott L (2009) Functional differences between $\mathrm{D}(1)$ and $\mathrm{D}(5)$ revealed by high resolution imaging on live neurons. Neuroscience 164:463-469. CrossRef Medline

Makino H, Malinow R (2009) AMPA receptor incorporation into synapses during LTP: the role of lateral movement and exocytosis. Neuron 64:381390. CrossRef Medline

Meltzer H (1989) Serotonergic dysfunction in depression. Br J Psychiatry Suppl 25-31. Medline

Miesenböck G, De Angelis DA, Rothman JE (1998) Visualizing secretion and synaptic transmission with $\mathrm{pH}$-sensitive green fluorescent proteins. Nature 394:192-195. CrossRef Medline

Morinville A, Cahill CM, Esdaile MJ, Aibak H, Collier B, Kieffer BL, Beaudet A (2003) Regulation of delta-opioid receptor trafficking via mu-opioid receptor stimulation: evidence from mu-opioid receptor knock-out mice. J Neurosci 23:4888-4898. Medline

Navinés R, Martín-Santos R, Gómez-Gil E, Martínez de Osaba MJ, Gasto C (2008) Interaction between serotonin 5-HT1A receptors and betaendorphins modulates antidepressant response. Prog Neuropsychopharmacol Biol Psychiatry 32:1804-1809. CrossRef Medline

Park M, Penick EC, Edwards JG, Kauer JA, Ehlers MD (2004) Recycling endosomes supply AMPA receptors for LTP. Science 305:1972-1975. CrossRef Medline

Patterson GH, Lippincott-Schwartz J (2002) A photoactivatable GFP for selective photolabeling of proteins and cells. Science 297:1873-1877. CrossRef Medline

Pearse BM (1976) Clathrin: a unique protein associated with intracellular transfer of membrane by coated vesicles. Proc Natl Acad Sci U S A 73: 1255-1259. CrossRef Medline

Peddie CJ, Davies HA, Colyer FM, Stewart MG, Rodríguez JJ (2008) Dendritic colocalisation of serotonin1B receptors and the glutamate NMDA receptor subunit NR1 within the hippocampal dentate gyrus: an ultrastructural study. J Chem Neuroanat 36:17-26. CrossRef Medline

Peddie CJ, Davies HA, Colyer FM, Stewart MG, Rodríguez JJ (2010) A subpopulation of serotonin $1 \mathrm{~B}$ receptors colocalize with the AMPA receptor subunit GluR2 in the hippocampal dentate gyrus. Neurosci Lett 485:251255. CrossRef Medline

Petrini EM, Lu J, Cognet L, Lounis B, Ehlers MD, Choquet D (2009) Endocytic trafficking and recycling maintain a pool of mobile surface AMPA receptors required for synaptic potentiation. Neuron 63:92-105. CrossRef Medline

Ramírez OA, Vidal RL, Tello JA, Vargas KJ, Kindler S, Härtel S, Couve A (2009) Dendritic assembly of heteromeric gamma-aminobutyric acid type B receptor subunits in hippocampal neurons. J Biol Chem 284: 13077-13085. CrossRef Medline

Renner M, Choquet D, Triller A (2009) Control of the postsynaptic membrane viscosity. J Neurosci 29:2926-2937. CrossRef Medline
Renner M, Lacor PN, Velasco PT, Xu J, Contractor A, Klein WL, Triller A (2010) Deleterious effects of amyloid beta oligomers acting as an extracellular scaffold for mGluR5. Neuron 66:739-754. CrossRef Medline

Rothberg KG, Heuser JE, Donzell WC, Ying YS, Glenney JR, Anderson RG (1992) Caveolin, a protein component of caveolae membrane coats. Cell 68:673-682. CrossRef Medline

Sari Y (2004) Serotonin1B receptors: from protein to physiological function and behavior. Neurosci Biobehav Rev 28:565-582. CrossRef Medline

Saxton MJ, Jacobson K (1997) Single-particle tracking: applications to membrane dynamics. Annu Rev Biophys Biomol Struct 26:373-399. CrossRef Medline

Scahill L, Hamrin V, Pachler ME (2005) The use of selective serotonin reuptake inhibitors in children and adolescents with major depression. J Child Adolesc Psychiatr Nurs 18:86-89. CrossRef Medline

Schmid CL, Raehal KM, Bohn LM (2008) Agonist-directed signaling of the serotonin $2 \mathrm{~A}$ receptor depends on beta-arrestin-2 interactions in vivo. Proc Natl Acad Sci U S A 105:1079-1084. CrossRef Medline

Scott L, Zelenin S, Malmersjo S, Kowalewski JM, Markus EZ, Nairn AC, Greengard P, Brismar H, Aperia A (2006) Allosteric changes of the NMDA receptor trap diffusible dopamine 1 receptors in spines. Proc Natl Acad Sci U S A 103:762-767. CrossRef Medline

Serge A, Fourgeaud L, Hemar A, Choquet D (2002) Receptor activation and homer differentially control the lateral mobility of metabotropic glutamate receptor 5 in the neuronal membrane. J Neurosci 22:3910-3920. Medline

Sourial-Bassillious N, Rydelius PA, Aperia A, Aizman O (2009) Glutamatemediated calcium signaling: a potential target for lithium action. Neuroscience 161:1126-1134. CrossRef Medline

Stanić D, Malmgren H, He H, Scott L, Aperia A, Hökfelt T (2009) Developmental changes in frequency of the ciliary somatostatin receptor 3 protein. Brain Res 1249:101-112. CrossRef Medline

Stenmark H, Olkkonen VM (2001) The Rab GTPase family. Genome Biol 2:REVIEWS3007. CrossRef Medline

Svenningsson P, Chergui K, Rachleff I, Flajolet M, Zhang X, El Yacoubi M, Vaugeois JM, Nomikos GG, Greengard P (2006) Alterations in 5-HT1B receptor function by 111 in depression-like states. Science 311:77-80. CrossRef Medline

Thorsen TS, Madsen KL, Rebola N, Rathje M, Anggono V, Bach A, Moreira IS, Stuhr-Hansen N, Dyhring T, Peters D, Beuming T, Huganir R, Weinstein H, Mulle C, Stromgaard K, Ronn LC, Gether U (2010) Identification of a small-molecule inhibitor of the PICK1 PDZ domain that inhibits hippocampal LTP and LTD. Proc Natl Acad Sci U S A 107:413-418. CrossRef Medline

Triller A, Choquet D (2003) Synaptic structure and diffusion dynamics of synaptic receptors. Biol Cell 95:465-476. CrossRef Medline

Wang H, Pickel VM (2001) Preferential cytoplasmic localization of deltaopioid receptors in rat striatal patches: comparison with plasmalemmal mu-opioid receptors. J Neurosci 21:3242-3250. Medline

Wang HB, Zhao B, Zhong YQ, Li KC, Li ZY, Wang Q, Lu YJ, Zhang ZN, He SQ, Zheng HC, Wu SX, Hökfelt TG, Bao L, Zhang X (2010) Coexpression of delta- and mu-opioid receptors in nociceptive sensory neurons. Proc Natl Acad Sci U S A 107:13117-13122. CrossRef Medline

Warner-Schmidt JL, Flajolet M, Maller A, Chen EY, Qi H, Svenningsson P, Greengard P (2009) Role of p11 in cellular and behavioral effects of 5-HT4 receptor stimulation. J Neurosci 29:1937-1946. CrossRef Medline

Wenthold RJ (1979) Release of endogenous glutamic acid, aspartic acid and GABA from cochlear nucleus slices. Brain Res 162:338-343. CrossRef Medline

Yu YJ, Arttamangkul S, Evans CJ, Williams JT, von Zastrow M (2009) Neurokinin 1 receptors regulate morphine-induced endocytosis and desensitization of mu-opioid receptors in CNS neurons. J Neurosci 29:222-233. CrossRef Medline

Yudowski GA, Puthenveedu MA, von Zastrow M (2006) Distinct modes of regulated receptor insertion to the somatodendritic plasma membrane. Nat Neurosci 9:622-627. CrossRef Medline 